\title{
Molecular Insight into the Therapeutic Promise of Flavonoids against Alzheimer's Disease
}

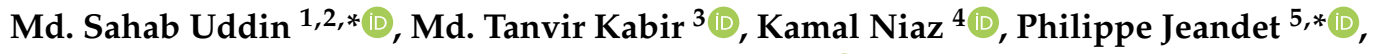 \\ Christophe Clément ${ }^{5}$, Bijo Mathew ${ }^{6}$, Abdur Rauf ${ }^{7} \mathbb{1}$, Kannan R.R. Rengasamy ${ }^{8}$, \\ Eduardo Sobarzo-Sánchez ${ }^{9,10}$ (D), Ghulam Md Ashraf 11,12 (D) and Lotfi Aleya ${ }^{13}$ \\ 1 Department of Pharmacy, Southeast University, Dhaka 1213, Bangladesh \\ 2 Pharmakon Neuroscience Research Network, Dhaka 1207, Bangladesh \\ Department of Pharmacy, BRAC University, Dhaka 1212, Bangladesh \\ 4 Department of Pharmacology and Toxicology, Faculty of Bio-Sciences, Cholistan University of Veterinary \\ and Animal Sciences (CUVAS), Bahawalpur 63100, Pakistan \\ 5 Research Unit, Induced Resistance and Plant Bioprotection, EA 4707, SFR Condorcet FR CNRS 3417, \\ Faculty of Sciences, University of Reims Champagne-Ardenne, PO Box 1039, 51687 Reims CEDEX 2, France \\ 6 Division of Drug Design and Medicinal Chemistry Research Lab, Department of Pharmaceutical Chemistry, \\ Ahalia School of Pharmacy, Palakkad, Kerala 678557, India \\ 7 Department of Chemistry, University of Swabi, Anbar 23561, Khyber Pakhtunkhwa, Pakistan \\ 8 Department of Bioresources and Food Sciences, Konkuk University, Seoul 05029, Korea \\ 9 Instituto de Investigación e Innovación en Salud, Facultad de Ciencias de la Salud, \\ Universidad Central de Chile, Santiago 8330507, Chile \\ 10 Department of Organic Chemistry, Faculty of Pharmacy, University of Santiago de Compostela, \\ 15782 Santiago de Compostela, Spain \\ 11 King Fahd Medical Research Center, King Abdulaziz University, Jeddah 21589, Saudi Arabia \\ 12 Department of Medical Laboratory Technology, Faculty of Applied Medical Sciences, \\ King Abdulaziz University, Jeddah 21589, Saudi Arabia \\ 13 Chrono-Environnement Laboratory, UMR CNRS 6249, Bourgogne Franche-Comté University, \\ F-25030 Besançon, France \\ * Correspondence: msu-neuropharma@hotmail.com or msu_neuropharma@hotmail.com (M.S.U.); \\ philippe.jeandet@univ-reims.fr (P.J.); Tel.: +880-1710220110 (M.S.U.); +33-3-26913-341 (P.J.)
}

Received: 6 February 2020; Accepted: 10 March 2020; Published: 11 March 2020

\begin{abstract}
Alzheimer's disease (AD) is one of the utmost chronic neurodegenerative disorders, which is characterized from a neuropathological point of view by the aggregates of amyloid beta $(A \beta)$ peptides that are deposited as senile plaques and tau proteins which form neurofibrillary tangles (NFTs). Even though advancement has been observed in order to understand AD pathogenesis, currently available therapeutic methods can only deliver modest symptomatic relief. Interestingly, naturally occurring dietary flavonoids have gained substantial attention due to their antioxidative, anti-inflammatory, and anti-amyloidogenic properties as alternative candidates for AD therapy. Experimental proof provides support to the idea that some flavonoids might protect AD by interfering with the production and aggregation of $A \beta$ peptides and/or decreasing the aggregation of tau. Flavonoids have the ability to promote clearance of $\mathrm{A} \beta$ peptides and inhibit tau phosphorylation by the mTOR/autophagy signaling pathway. Moreover, due to their cholinesterase inhibitory potential, flavonoids can represent promising symptomatic anti-Alzheimer agents. Several processes have been suggested for the aptitude of flavonoids to slow down the advancement or to avert the onset of Alzheimer's pathogenesis. To enhance cognitive performance and to prevent the onset and progress of $\mathrm{AD}$, the interaction of flavonoids with various signaling pathways is proposed to exert their therapeutic potential. Therefore, this review elaborates on the probable therapeutic approaches of flavonoids aimed at averting or slowing the progression of the $\mathrm{AD}$ pathogenesis.
\end{abstract}


Keywords: Alzheimer's disease; flavonoids; amyloid plaque; neurofibrillary tangles; PI3K/Akt signaling; MAPK signaling; mTOR

\section{Introduction}

Alzheimer's disease (AD) is a form of dementia that most commonly affects older people and is characterized by progressive cognitive decline, which usually starts with a decrease in memory $[1,2]$. AD is characterized by profound oxidative stress, synaptic connection loss from a specific brain regions, cumulative emergence of intracellular tau pathology, and buildup of extracellular amyloid beta $(\mathrm{A} \beta)$ plaques $[3,4]$. The harmful activities of free radicals and oxidized metabolites in AD include DNA oxidation, lipid peroxidation, and protein oxidation, which ultimately leads to neuronal death [5-8]. Significant advancement has been achieved to understand AD pathogenesis, since currently available therapeutic methods only deliver moderate relief of cognitive symptoms, such as impairments in perception and memory [9-11]. Although, for drug developers, AD has proven to be tremendously challenging, researchers continue to discover better anti-Alzheimer's treatments. The Food and Drug Administration (FDA) has approved a small number of medications to treat $\mathrm{AD}$; these approved medications are found to improve symptoms, but nonetheless do not change the means of disease advancement and have even exhibited specific undesired effects [12,13]. Biogen Inc. (an American multinational biotechnology company) stopped the phase III clinical trials of the blockbuster anti-Alzheimer's drug, aducanumab in March 2019, owing to safety concerns [14]. However, in October 2019, they declared that further analysis exposed momentous positive effects for aducanumab in patients with early $\mathrm{AD}$ [15]. Owing to the complex nature of $\mathrm{AD}$, there is a growing need for natural substances to treat neurodegenerative events of AD progression [16-20].

In several pathological conditions, for example, neurodegenerative diseases, diabetes, and cancer, natural products endure as a promising source of various molecular characteristics, biochemical specificity, and enormous chemical diversity, which makes these natural products appropriate for the modification of many signaling cascades [21-24]. Flavonoids are commonly found in various vegetables, fruits, and plants $[25,26]$. These natural substances are well-recognized as displaying a variety of pharmacological actions $[19,27]$ and also serve as potent metal chelators, free radical scavengers, and antioxidant agents [27-30]. Flavonoids are also found to subdue the microglial activation, to mediate inflammatory processes in the central nervous system (CNS) [31], to possess potent anti-amyloidogenic, antidepressant effects [32], as well as to improve memory and learning ability [33]. In addition, these natural substances exhibit anti-inflammatory [34-36], neuroprotective [37,38], antiaging [39], and anticholinesterase [40] properties.

Acute or chronic administration of flavonoids can penetrate the blood-brain barrier (BBB) signifying that these compounds can operably have a direct impact on the brain. The latter remark suggests that flavonoids can practically have a direct action in the brain; henceforth, these natural substances might be used as a prophylactic, to slow down the advancement of AD [29]. This review thus aims to focus on the molecular mechanisms of plant-derived flavonoids to increase the survivability of neuronal cells in $\mathrm{AD}$ and to lower the risk of cellular degeneration.

\section{Aging and Age-Associated Changes in the Brain}

Out of the pathophysiological alterations that takes place in the aging brain, the major changes that potentially contribute to neurodegeneration include a rise in oxidative stress, loss of neurotrophic support, changes in energy metabolism, changes in protein processing causing a buildup of protein aggregates, dysfunction of the neurovascular system, and activation of the immune system [41-43]. Therefore, it is pretty evident that targeting a single alteration will not be effective at averting nerve cell death and damage. Furthermore, there is a strong chance that the extent of the aforesaid alterations will differ among people. Indeed, the latter interact with environmental, lifestyle, and genetic risk 
factors to varying extents. For example, even though $\mathrm{AD}$ is defined in terms of toxic tangle and plaque pathology, it is most commonly related to other harmful processes, for example, inflammation and microvascular damage [44].

Therefore, for the effective prevention of these age-associated alterations of the brain, it is essential to use combination of drugs directed against different targets. Nevertheless, several potential problems are involved with this technique including bioavailability and pharmacokinetic challenges. These problems are even more prominent in case of brain diseases, where it is difficult to get multiple compounds across the BBB and where there are also increased chances of adverse drug-drug interactions. Thus, a better technique would be the identification of small molecules which have several biological actions affecting a multiplicity of age-related pathophysiological alterations, and which play a role in the development and progression of neurodegeneration [45].

\section{Alzheimer's Disease Hallmarks}

\subsection{Amyloid Plaques}

In the onset and advancement of $\mathrm{AD}, \mathrm{A} \beta$ plays a crucial role and is considered a vital risk factor [46,47]. Production of the $A \beta$ peptide is typical in healthy people and its production rate (i.e., $7.6 \%$ ) is normally lower than its rate of clearance (i.e., 8.3\%) per hour [48]. However, A $\beta$ might form aggregates under certain conditions and initiate the progression of the disease. In cases of AD and neuronal dysfunctions, there are several shreds of evidence denoting the vital contribution of $A \beta[49,50]$. An imbalance in $A \beta$ formation and $A \beta$ clearance $[51,52]$ may occur in pathological and aging situations, for example, excitotoxicity and metabolic disorders, which can eventually lead to $A \beta$ accumulation and the formation of senile plaques [53]. In case of $A D$, the disproportion of the level of $A \beta$ might be because of its disturbance in generation and clearance in the brain.

In the Alois Alzheimer's original case report, it was mentioned that both the abnormal extracellular buildup and the deposition of $A \beta$ with 42 or 40 amino acids (i.e., $A \beta_{1-42}$ and $A \beta_{1-40}$ ) are normal byproducts of the metabolism of the amyloid precursor protein (APP) through an enzymatic sequential cleavage via the $\beta$ - and $\gamma$-secretases in neurons. On the other hand, $A \beta 42$ is more abundant and pathogenic as compared to $\mathrm{A} \beta 40$ due to its higher rate of insolubility and fibrillation within the plaques [54].

\subsection{Neurofibrillary Tangles}

Tau is an abundantly found neuronal microtubule-associated protein which is produced by neurons. Tau is localized in the axons and the cell body of neurons [55]. During neuronal development, the expression of tau is increased by the nerve growth factor under normal circumstances [56]. However, tau is also generated via glial cells under various pathological conditions $[57,58]$. CNS is the prime region of tau expression, while its mRNA can also be found in peripheral tissues [58]. It is assumed that neuronal death and production of NFTs are the results of tau abnormalities, which can ultimately cause dementia [59]. In the somatodendritic region of the neurons, tau accumulates in its hyperphosphorylated forms [56]. On the other hand, NFTs formation is directly linked with neuronal dysfunction; furthermore, the number of NFTs is associated with the extent of dementia in AD [60].

In the Alois Alzheimer's original autopsy case report, it was first stated that within the perikaryal region of pyramidal neurons, NFTs were mentioned as intraneuronal filamentous inclusions. It was revealed through ultrastructure experiments on AD brain specimens that NFTs are primarily composed of paired helical filaments (PHFs), which are fibrils of approximately $10 \mathrm{~nm}$ in diameter that form pairs with a helical three-dimensional conformation and a regularly repeated pattern of almost $65 \mathrm{~nm}$ [61-63]. Interestingly, the presence of fibrils inside the NFTs in a small proportion does not cause the formation of pairs but leads to straight filaments without the repeated pattern of PHFs [64]. A study reported the existence of twisted ribbon-like assemblies of tau fibrils in in vitro models, therefore challenging the theory of PHFs [65]. 


\section{Proteolytic Processing of APP and A $\beta$ Production}

The APP is a type I transmembrane protein containing a large extracellular domain. Furthermore, it includes a hydrophobic transmembrane domain and a short C-terminus, designated the APP intracellular domain (AICD), which can go through alternative splicing and can give rise to at least eight isoforms of APP [66]. APP can be proteolytically processed via two distinct pathways such as the amyloidogenic pathway and the non-amyloidogenic pathway with the help of the $\alpha-, \beta-$, and $\gamma$-secretases [67], as shown in Figure 1. The biochemical characteristics of these secretases have been elucidated. It has been proposed that three members of the disintegrin and metalloprotease (ADAM) family; the metalloproteinases ADAM10, ADAM9, and the ADAM17/tumor necrosis factor- $\alpha$ converting enzyme (TACE) $[68,69]$ may exhibit $\alpha$-secretase activity. On the other hand, the $\beta$-secretase activity has been mainly ascribed to the $\beta$-site APP-cleaving enzyme (BACE1) [70-73]. Subsequent cleavage by the $\alpha$-secretase and $\gamma$-secretase complex prevents the formation of $A \beta$ in the non-amyloidogenic pathway. In fact, $\alpha$-secretase cleavage originates the membrane-linked C-terminal fragment consisting of 83 amino acids (CTF83), which is subsequently cleaved via the $\gamma$-secretase complex, ultimately leading to AICD and P3 peptide [74].

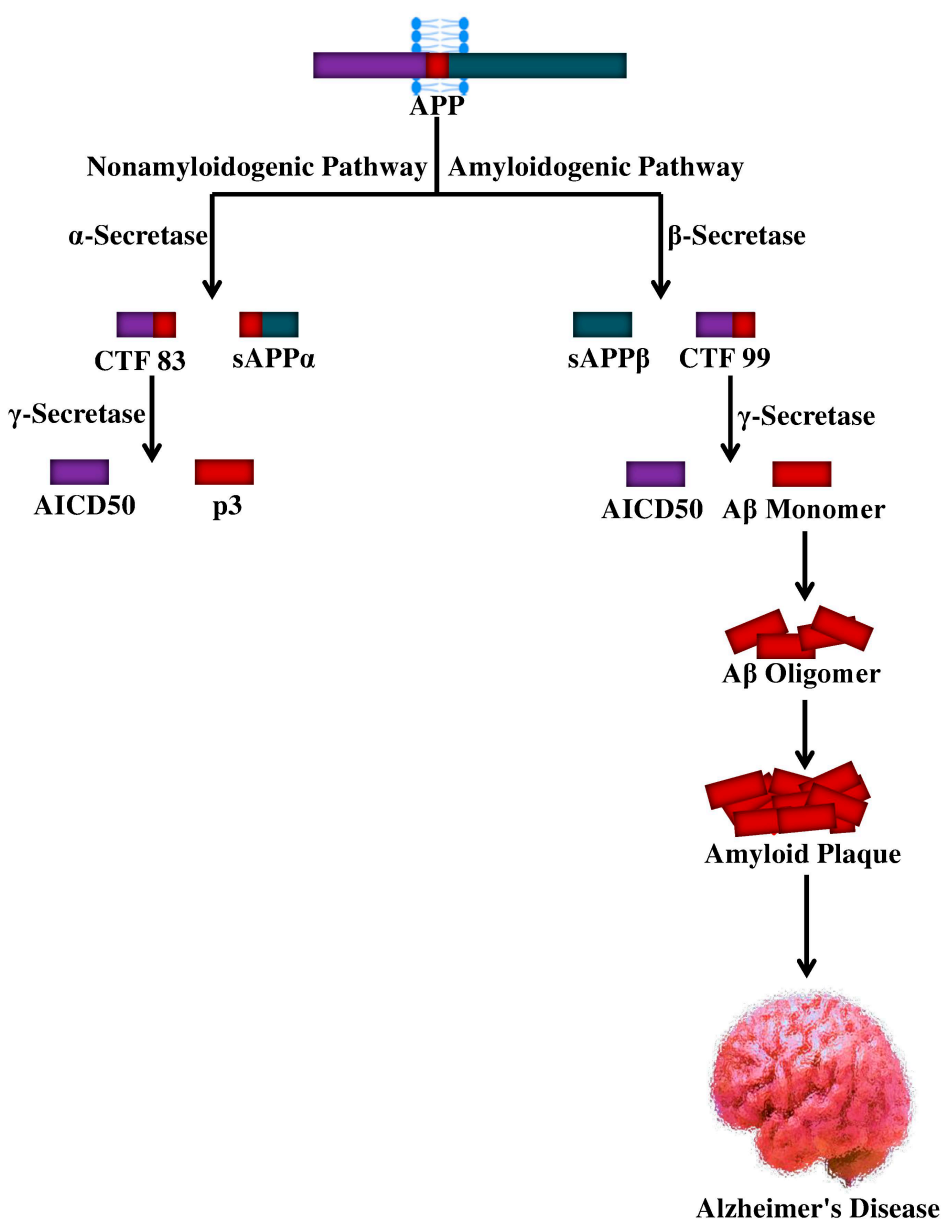

Figure 1. Cellular processing of amyloid precursor protein and the genesis of A $\beta$ peptide. APP, amyloid precursor protein; SAPP, soluble amyloid precursor protein; CTF, C-terminal fragment; $A \beta$, amyloid beta; AICD, APP intracellular domain; p3, peptide p3.

Interestingly, as per the amyloidogenic pathway, the $\beta$-secretase can process the APP to generate a membrane-linked C-terminal fragment consisting of 99 amino acids (CTF99) and a soluble APP $\beta$ $(\mathrm{sAPP} \beta)$ fragment. The former sAPP $\beta$ is also a substrate for the $\gamma$-secretase complex, the cleavage of which leads to AICD release and A $\beta$ generation, which can span from 1-38 to 1-43 residues. Though $A \beta_{1-42}$ is a minor species, $A \beta_{1-40}$ is mainly generated under non-pathological circumstances $[75,76]$. 
APP trafficking and processing can be influenced by various factors, including A $\beta$ itself [77-79] and stress conditions [80,81]. Along with the formation of NFTs and the hyperphosphorylation of tau [82], several pathological events including neuroinflammation, oxidative stress, apoptosis, and neurotoxicity can take place due to excessive production of $A \beta$ [83-85]. In certain brain areas of AD individuals, the abnormalities mentioned above can lead to neuronal loss and synaptic damage, further causing the progression of the disease [86].

\section{Phosphatases and Kinases for Tau Phosphorylation}

As was previously evocated, the hyperphosphorylation of tau is another hallmark of AD. Tau phosphorylation controls its binding action to microtubules triggering their assembly. On the other hand, tau loses its biological activity in the hyperphosphorylated state [87], basal levels of phosphorylation being essential for optimum tau effect (Figure 2). It has been reported that twenty-eight phosphorylation sites of tau (i.e., among approximately eighty-five phosphorylation sites) are mainly phosphorylated in AD brains [88].

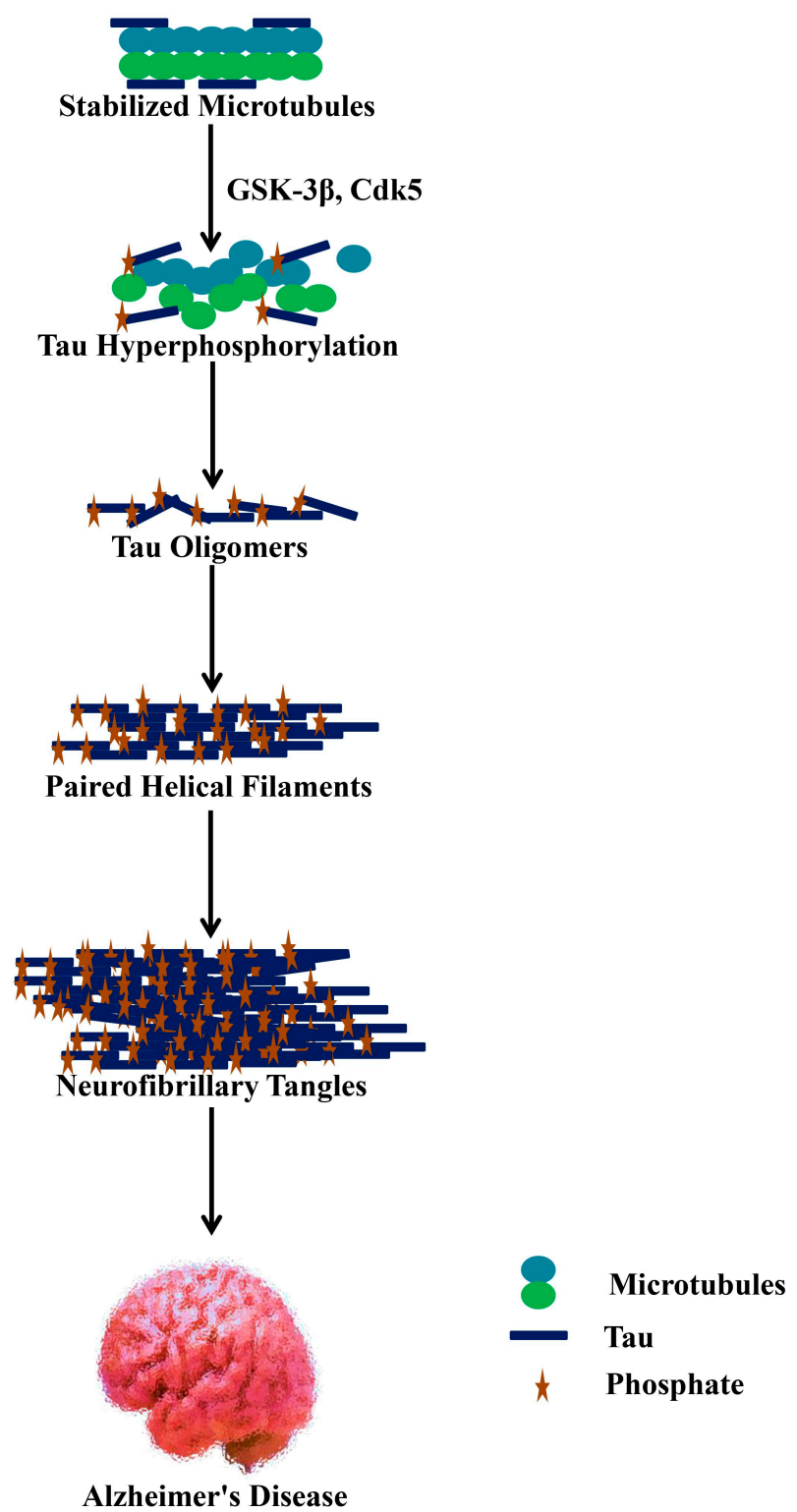

Figure 2. Hyperphosphorylated tau dissociates from microtubules and depolymerizes as well as aggregates as neurofibrillary tangles. GSK-3 $\beta$, glycogen synthase kinase $3 \beta$; Cdk5, cyclin-dependent kinase 5. 
It is supposed that the downregulation of tau phosphatase(s) or the upregulation of tau kinase(s) in case of $\mathrm{AD}$ can cause abnormal phosphorylation of tau, even though both events might not be mutually exclusive [58]. cAMP-dependent protein kinase (PKA), calcium/calmodulin-dependent kinase II (CaMK-II), cyclin-dependent kinase 5 (Cdk5) and glycogen synthase kinase $3 \beta$ (GSK-3 $\beta$ ) are the kinases that are predicted to have a substantial contribution to the phosphorylation of brain tau [89]. Interestingly, among tau kinases, GSK-3 $\beta$ might have a significant impact on controlling the phosphorylation of tau under both pathological and physiological conditions. Furthermore, GSK-3 $\beta$ can cause the phosphorylation of tau at multiple residue levels. Protein phosphatases (PP) 1, PP2A, PP2B (calcineurin), and PP2C are all potential candidates that can dephosphorylate tau [90]. As a whole, when compared to non-demented older adults, tau is at least 3- to 4-times more hyperphosphorylated in the brain of $\mathrm{AD}$ patients [91].

\section{Flavonoids}

Growing evidence confirms that flavonoids display promising neuroprotective potential due to their ability to lessen the progression of age-related neurodegenerative disorders or avert the onset of neurodegeneration [92,93]. Their attitudes to influence learning and cognition in animal models of disease and also in humans have been exhibited by dietary supplementation experiments involving flavonoid-rich food or plant extracts [94-98]. In the brain, the possible beneficial effect of flavonoids appears to be linked to their potential to interact with glial signaling and intracellular neuronal pathways, therefore triggering neuronal regeneration, increasing existing functions of the neurons, protecting vulnerable neurons, or affecting the cerebrovascular and peripheral system [99]. In plants, flavonoids are naturally-occurring polyphenolic compounds [92,100]. Furthermore, they can be found in beverages and foods of the plant source, for example, a range of vegetables, fruits, wine, tea, cereals and cocoa [101,102]. The six major subclasses of flavonoids [103] are given in Table 1 and Figure 3.

Table 1. Classification of flavonoids and their dietary sources.

\begin{tabular}{|c|c|c|}
\hline Class & Flavonoids & Dietary Sources \\
\hline Flavanones & $\begin{array}{l}\text { Naringin, } \\
\text { Naringenin, } \\
\text { Hesperetin, } \\
\text { Eriodictyol }\end{array}$ & Tomatoes, grapefruits and citrus fruits \\
\hline Flavanols & $\begin{array}{l}\text { Epigallocatechin gallate, } \\
\text { Epigallocatechin, } \\
\text { Epicatechin, } \\
\text { Catechin }\end{array}$ & Cocoa, red wine, grapes, and green tea \\
\hline Flavones & $\begin{array}{l}\text { Luteolin, } \\
\text { Diosmin, } \\
\text { Apigenin, } \\
\text { Wogonin }\end{array}$ & $\begin{array}{l}\text { Broccoli, onions, oranges, parsley, } \\
\text { grapefruit, cabbage, and carrot }\end{array}$ \\
\hline Flavonols & $\begin{array}{l}\text { Quercetin, } \\
\text { Morin, } \\
\text { Galangin, } \\
\text { Kaempferol }\end{array}$ & $\begin{array}{l}\text { Tea, apples, onions, broccoli, strawberries, } \\
\text { leeks, and grapefruits }\end{array}$ \\
\hline Anthocyanins & $\begin{array}{l}\text { Malvidin, } \\
\text { Cyanidin, } \\
\text { Hirsutidin, } \\
\text { Pelargonidin }\end{array}$ & Kidney beans, red wine, and berry fruits \\
\hline Isoflavones & $\begin{array}{l}\text { Genistein, } \\
\text { Glycitein, } \\
\text { Daidzein, } \\
\text { Equol }\end{array}$ & Soy and soy products \\
\hline
\end{tabular}


<smiles>COc1ccc([C@H]2CC(=O)c3c(O)cc(O)cc3O2)cc1O</smiles>

(Epicatechin)<smiles>O=c1c(O)c(-c2ccc(O)cc2)oc2cc(O)cc(O)c12</smiles><smiles></smiles>

Figure 3. Chemical structure of the major classes of flavonoids.

It was assumed that the potential role of flavonoids in stimulating cognitive functions, learning, and memory is mediated by their antioxidant capabilities [104]. However, growing evidence shows that these natural substances are able to interact with the molecular and cellular components of the brain accountable for memory. Flavonoids have the potential to encourage neurogenesis, trigger neuronal regeneration, increase existing neuronal function, and prevent neuronal dysfunction (Table 2) [104,105]. 
Table 2. Promising preclinical studies of flavonoids and their neuroprotective role against Alzheimer's disease.

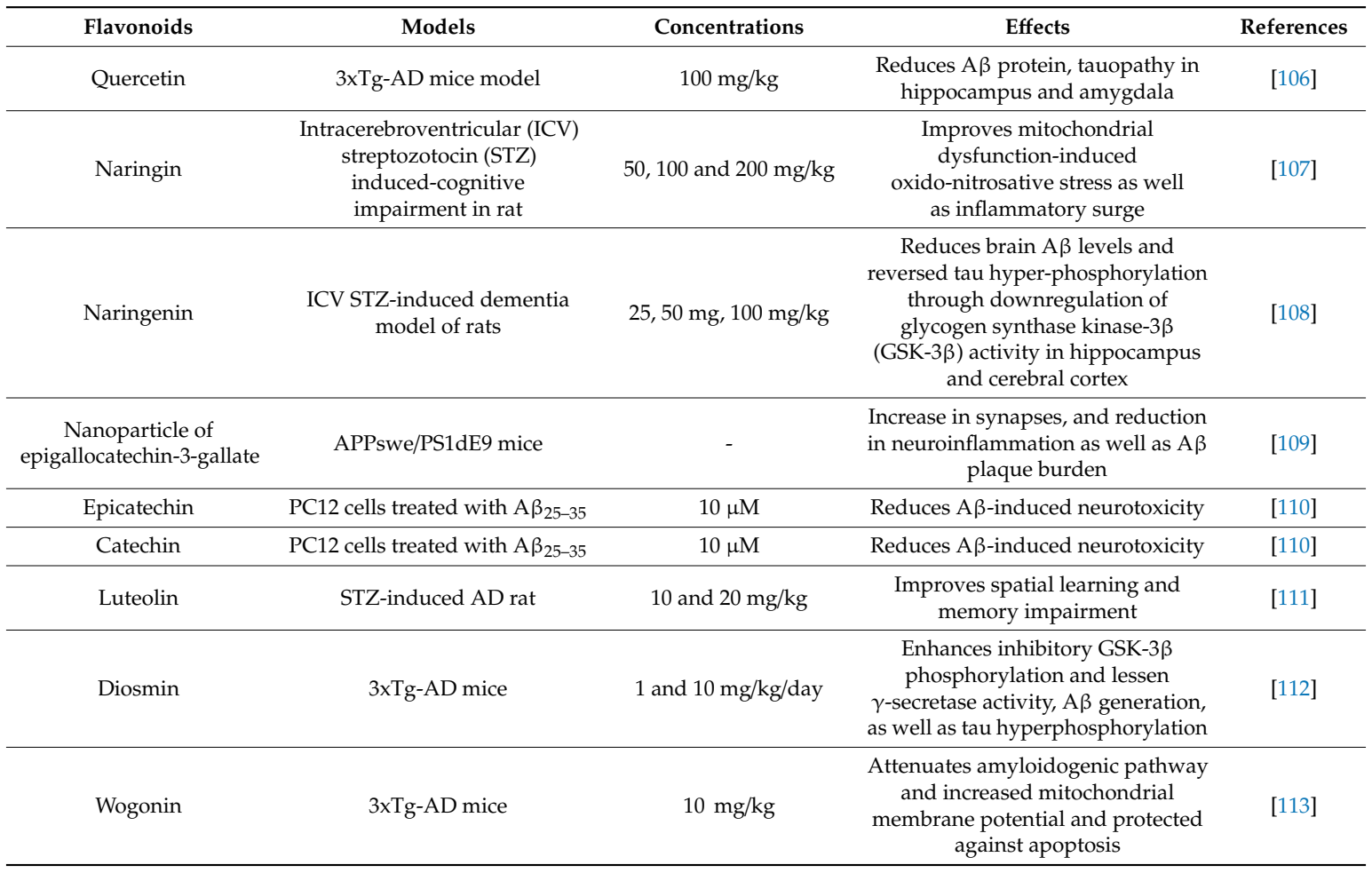

\section{Role of Flavonoids on Alzheimer's Hallmarks}

\subsection{A $\beta$ Neuropathology}

A variety of flavonoids have been reported to reverse cognitive impairments and to inhibit $\mathrm{AD}$ development, suggesting their potential for therapeutic applications [114-116]. Various experiments have focused on the anti-amyloidogenic properties of flavonoids (Figure 4), as a critical natural remedy to lessen AD [117,118]. Henceforth, it has recently been proven in APP/PS1 mouse models of AD that blackcurrant and anthocyanin-enriched bilberry extracts can reduce behavioral abnormalities associated with AD and regulate APP processing [119]. On the other hand, transgene-linked defective spatial reference memory and behavioral impairment in a transgenic PSAPP mouse model of cerebral amyloidosis were averted with orally administered tannic acid for six months. Additionally, several different experiments have reported on the efficacy of flavonoids in learning and memory. A citrus flavonoid, nobiletin, was found to reduce the burden of $A \beta$ and plaques in the hippocampus region, thus improving the memory deficits induced by $\mathrm{A} \beta$ in a transgenic $\mathrm{AD}$ mouse model [120]. It was also reported that reduced cognitive impairment coincides with decreased levels of high-molecular-weight soluble $A \beta$ oligomers upon oral administration of grape-derived polyphenols for five months in the brain of Tg2576 mice [121].

The citrus flavonoid, luteolin was found to reduce the processing of APP by the amyloidogenic $\gamma$-secretase activity and decrease the generation of $A \beta$ in both human Swedish mutant APP transgene-bearing neuron-like cells and primary neurons [122] as shown in Figure 4. Furthermore, the deposition of $A \beta$ was averted due to the administration of curcumin or polyphenol-rich grape seed extracts for nine months in the brain of AD mouse models [123]. 


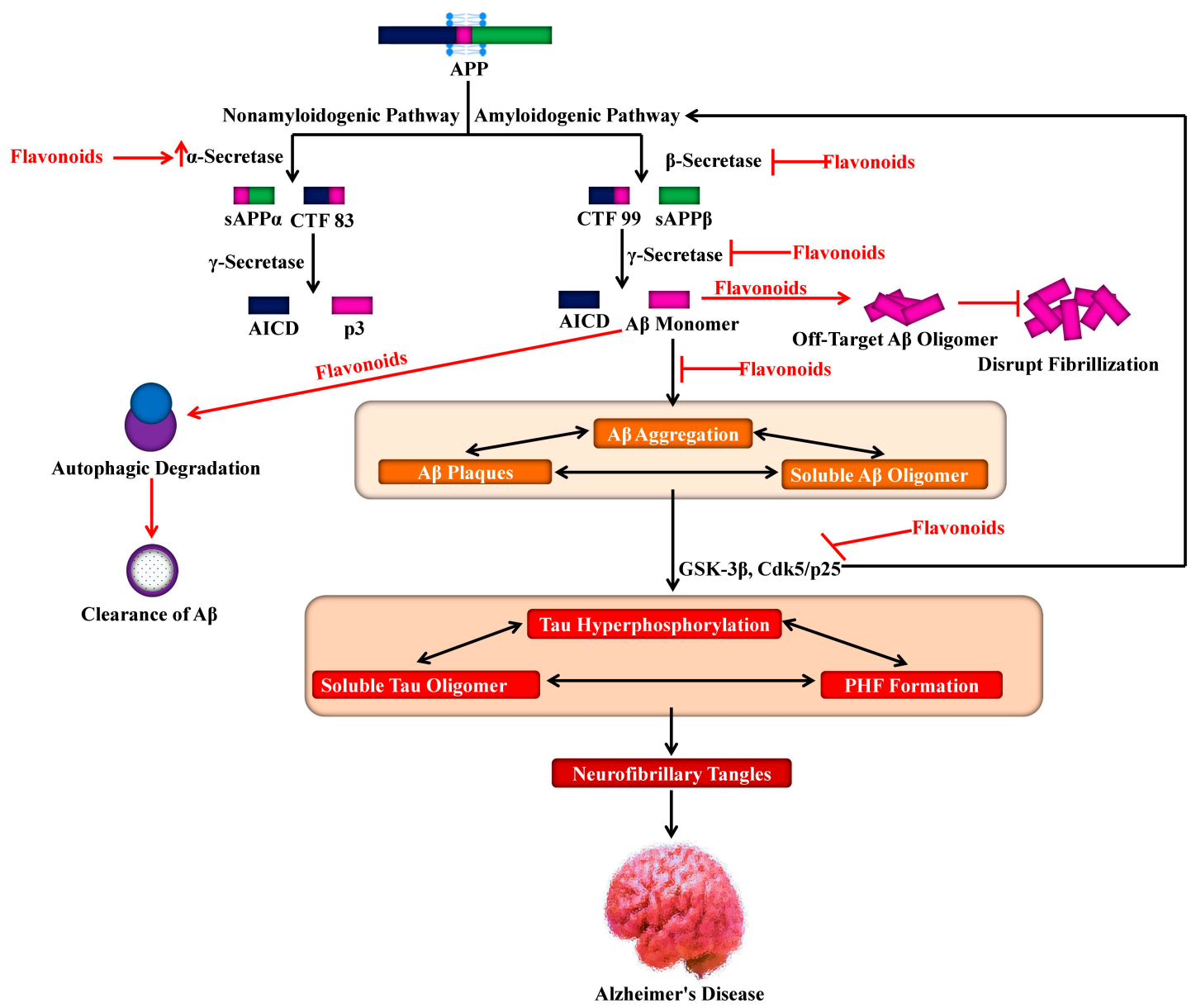

Figure 4. Role of flavonoids in targeting amyloid precursor protein processing for lessening Alzheimer's pathogenesis. APP, amyloid precursor protein; $\mathrm{SAPP}$, soluble amyloid precursor protein; CTF, C-terminal fragment; $A \beta$, amyloid beta; AICD, APP intracellular domain; $\mathrm{p} 3$, a peptide; GSK-3 $\beta$, glycogen synthase kinase $3 \beta$; Cdk5, cyclin-dependent kinase 5 .

In a transgenic $\mathrm{AD}$ mouse model, it was found that long-term administration (i.e., sixteen months) of Ginkgo biloba extracts considerably decreased the levels of APP, further proposing the potential neuroprotective properties of these extracts associated to APP-reducing activities [124]. It has also been reported that cerebral vascular and brain parenchymal $A \beta$ deposits were reduced in tannic acid-treated PSAPP mice, signifying that tannic acids play a role as natural inhibitors of $\beta$-secretase [125]. On the other hand, the reduction in secreted A $\beta$ levels and active inhibition of BACE- 1 activity were observed in primary cortical neurons following the use of natural flavonoids [126]. Epigallocatechin-3-gallate (ECG) and curcumin were found to reduce $A \beta$-mediated BACE-1 upregulation in neuronal cultures [127].

Several experiments have been directed toward identifying the beneficial properties of regular green tea intake. It has indeed been demonstrated that a green tea polyphenol such as ECG has a beneficial contribution in terms of reducing brain A $\beta$ levels through the control of the APP processing $[128,129]$. Interestingly, ECG causes elevation of the nonamyloidogenic processing of APP by enhancing $\alpha$-secretase cleavage [130]. It was also reported that ECG arbitrated the augmentation of the non-amyloidogenic APP processing via ADAM10 maturation through an estrogen receptor- $\alpha /$ phosphoinositide 3-kinase/Ak-transforming-dependent mechanism. Modulating selective estrogen receptors might be a therapeutic target, as a decrease in the level of estrogens after menopause is associated with an elevated risk of AD development [131]. On the other hand, ECG might be considered in the treatment and prophylaxis of AD as a substitute for estrogen therapy [132].

Since ECG possesses the ability to reduce the formation of the $\beta$-sheet-rich amyloid fibrils, it might have a neuroprotective effect. It has been confirmed that this compound reduces the 
$A \beta$ fibrillogenesis via its direct binding to the natively unfolded polypeptides thus averting their conversion into toxic intermediates [133]. Interestingly, it has been observed that ECG has the power to convert large $A \beta$ fibrils into smaller ones, amorphous protein aggregates that are non-toxic in nature. This phenomenon signifies that ECG is a powerful remodeling agent for amyloid fibrils [134]. Additionally, other flavonoids also exhibited anti-amyloidogenic features, particularly myricetin, which displayed anti-amyloidogenic activity in in vitro models via reversibly and specifically binding to the amyloid fibril structure of $A \beta$, instead of monomers of $A \beta[135,136]$. In general, these experiments report that specific flavonoids can disturb fibrillation by leading to the generation of off-target $A \beta$ oligomers (Figure 4), and function by increasing the activity of ADAM10, or act as BACE-1 inhibitors, subsequently decreasing the production of $A \beta$.

Most of the consumed dietary polyphenols do not get absorbed by the upper intestinal tract. Gut microbiota helps in breaking these dietary polyphenols into low-molecular-weight phenolic compounds in the colon, which are more effectively absorbed by the gastrointestinal epithelial cells $[137,138]$. A study has revealed that the administration of grape seed polyphenol extracts in mice caused the formation of 11 unique polyphenol metabolites as measured in urine, four metabolites in the plasma, whereas only two metabolites, 3-(3'-hydroxyphenyl) propionic acid and 3-hydroxybenzoic acid, were detected in the brain following perfusion [139]. Both 3-(3'-hydroxyphenyl) propionic acid and 3-hydroxybenzoic acid are likely derivatives of the flavonol quercetin, and are generated following ring cleavage of the latter by Enterobacter spp. in the gut and enterocyte phase II modification, for instance, dehydration or reduction [140]. In the study of Wang et al. [141], it was reported that 3-( $3^{\prime}$-hydroxyphenyl) propionic acid and 3-hydroxybenzoic acid have a strong ability to attenuate $\mathrm{A} \beta$ oligomerization in AD.

Nevertheless, further experiments are needed to identify which flavonoid structures contain potent beneficial properties and their underlying mechanisms of action. In a recent review, three structural characteristics of natural products have been proposed to explain their inhibitory activity against the aggregation of $A \beta 42$ [142]. The first characteristic is that carboxy acid derivatives with anthraquinoids or triterpenoids which are able to produce a salt bridge with basic amino acid residues such as Lys28 and Lys16 in the A $\beta 42$ trimers or dimers. The second characteristic involves non-catechol-type flavonoids with molecular planarity because of $\alpha, \beta$-unsaturated carbonyl groups that have the ability to interact with the intermolecular $\beta$-sheet region in $A \beta 42$ aggregates, particularly aromatic rings, such as those of Phe20 and Phe19. The third characteristic includes catechol-type flavonoids that can produce Michael adducts with the side chains of Lys28 and Lys16 in monomeric A $\beta 42$ by flavonoid autoxidation [142].

\subsection{Tau Neuropathology}

In $\mathrm{AD}$, flavonoids might contribute to downstream targets, for instance, phosphorylation of tau. Relating to this, several experiments have explained the characteristics of the action of flavonoids in tau, which might influence AD. In the transgenic AD mouse model, the administration of ECG was found to modulate the profiles of tau, along with prominent suppression of the phosphorylated tau isoforms (i.e., sarkosyl-soluble) [129]. In contrast, epicatechin-5-gallate and myricetin were found to inhibit the heparin-mediated formation of tau [143]. Other experiments using grape-derived polyphenols have revealed their aptitude to hinder the neuropathology of tau in an AD mouse model, delaying aggregations of tau, and disrupting PHFs and dissociating preformed tau aggregates [142-147].

Various kinases including GSK-3 $\beta$, play a role in tau phosphorylation and are involved in $\mathrm{AD}$ pathogenesis. It has been observed that the activities of several kinases are suppressed by flavonoids, and therefore the latter can help in AD prevention. In this regard, for example, activities of protein kinases including GSK-3 $\beta$ and $C d k 5 / p 25$ can be inhibited by indirubins, which are byproducts of bacterial metabolism. These two protein kinases (Figure 4) are involved in abnormal tau phosphorylation, which is observed in AD patients [148]. It has been reported that morin, a flavonoid, can inhibit GSK-3 $\beta$-mediated tau phosphorylation and can also suppress the activity of GSK-3 $\beta$. Additionally, morin gives protection against $\mathrm{A} \beta$-induced neurotoxicity in human neuroblastoma cells 
and also reduces the tau phosphorylation mediated by $\mathrm{A} \beta$. Moreover, in the hippocampal neurons of transgenic animals (3xTg-AD mice), treatment with morin was shown to cause a reduction in tau hyperphosphorylation [149]. It has also been observed that cyanidin-3-O-glucoside provided marked protection against cognitive dysfunctions stimulated by $\mathrm{A} \beta$ administration in animal models, which is mediated by modulation of GSK-3 $\beta /$ tau [150]. On the other hand, luteolin is found to cause a reduction in GSK-3 activity and in the levels of soluble A $\beta$ as well as disruption in PS1-APP association [122].

\section{Role of Flavonoids in the Signaling Pathways of Alzheimer's Disease}

It has been indicated through copious evidence that certain flavonoids [151] and their various metabolites [152-154] can exert useful actions on neurological processes via their interaction with various neuronal signaling pathways. The tyrosine kinase receptor B (TrkB) [155], as well as nicotinic acetylcholine [156,157], $\delta$-opioid [158,159], type A gamma-aminobutyric acid $\left(\mathrm{GABA}_{\mathrm{A}}\right)$ [160-162], adenosine [163], testosterone [164] and estrogen [132] receptors, represent potential flavonoid-binding sites on neurons [165]. Interestingly, flavonoids and their metabolites were found to exert effects on neurons via their interactions with various protein kinase- and lipid kinase-signaling cascades, for instance, the nuclear factor kappa-light-chain-enhancer of activated B cells (NF- $\mathrm{B}$ ) pathway as well as the protein kinase C (PKC), tyrosine kinase, phosphoinositide-3-kinase (PI3K)/Akt, and mitogen-activated kinase (MAPK) signaling pathways [104,105,152,166-172].

MAPKs are found to control several cellular processes by transducing extracellular signals into intracellular responses $[173,174]$. On the other hand, flavonoids and their metabolites can selectively interact with the MAPK signaling pathways $[169,175]$ through their interaction with some MAPK kinases such as MAP kinase 1 (MEK1) as well as MEK2 and membrane receptors [169,176,177]. The effect of flavonoids on the extracellular signal-regulated kinase (ERK) pathway seems to be facilitated by these kinases [152,171,178-181]. Flavonoids contain a close structural homology to some specific pharmacological modulators of the ERK signaling pathway, for instance, PD98059 (2'-amino-3'-methoxyflavone, (MEK1 inhibitor)). It has also been observed that activation of the cAMP response element-binding protein (CREB) can take place due to ERK activation; eventually, this can cause an upregulation in neuroprotective pathways and alterations in memory and synaptic plasticity [182,183]. Blueberry contains high amounts of anthocyanins and flavanols. A study has revealed that the memory performance of rats supplemented with blueberry was associated with CREB activation and with rises in both mature and pro levels of the brain-derived neurotrophic factor (BDNF) in the hippocampus [184], both of which were found to be linked to the regulation of long-term memory and synaptic plasticity. Furthermore, in senescence-accelerated mouse prone- 8 mice, the intake of green tea catechins for six months averted memory deficits and spatial learning by enhancing the action of the protein kinase $A / C R E B$ pathway, reducing $A \beta_{42}$ oligomers, and through the upregulation of synaptic plasticity-related proteins in the hippocampus [185]. Likewise, flavonoids can cause stabilization of the nuclear factor erythroid 2-related factor 2 (Nrf2) and the hypoxia-inducible factor-1 [186], which act as modulators of PPAR- $\gamma$ [187] and activate the PGC-1 $\alpha$ [188] pathway. An alteration in these molecular pathways by flavonoids attenuates AD progression with a lessening of the oxidative stress, the improvement in mitochondrial dysfunction, the reduction in insulin resistance and an amelioration of the memory injury.

In addition, flavonoids regulate PI3K through direct interactions with their adenosine triphosphate (ATP)-binding site $[167,189]$ as shown in Figure 5. Based on the structure of quercetin, the most selective PI3K inhibitor, LY294002, was modeled [170,190]. Quercetin and LY294002 [191] fit into the binding pocket of the enzyme, although in various directions [191]. The extent of unsaturation of the C2-C3 bond in the C- ring and the number of hydroxyl (-OH) group substitutions on the flavonoid B-ring are crucial determining factors of this particular bioactivity. Furthermore, it seems that cellular responses can vary from one flavonoid to another, reliant on their degree of interaction with either downstream kinases or receptors, suggesting possible structure-dependent signaling pathways. 


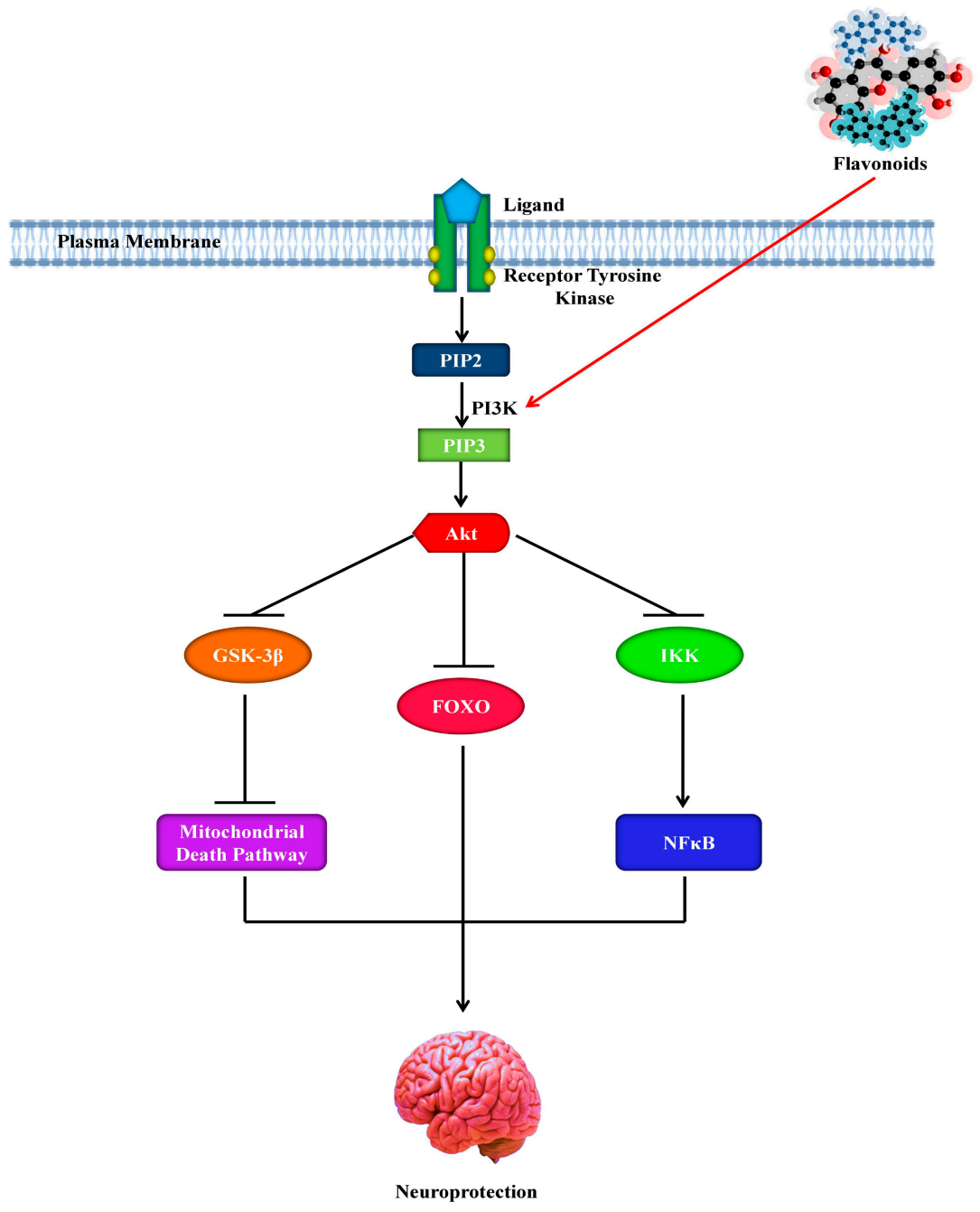

Figure 5. Neuroprotective effect of flavonoids by activating the phosphoinositide 3-kinase pathway. PI3K, phosphoinositide 3-kinase; GSK-3 $\beta$, glycogen synthase kinase $3 \beta$; Akt, protein kinase B; PIP2, phosphatidylinositol-3,4-biphosphate; PIP3, phosphatidylinositol-3,4,5-triphosphate; FOXO, forkhead box; NFkB, nuclear factor $\kappa \mathrm{B}$; IKK, IкB kinase.

Regarding this, the flavanone, hesperetin, for instance, has been found to cause activation of the Akt/protein kinase B (PKB)-signaling pathway to confer prosurvival properties in cortical neurons [181], while the flavonol, quercetin and its specific in vivo metabolites were found to modulate the prosurvival Akt/PKB- and ERK1/2-signaling pathways by hindering the activity of PI3K [152]. ECG has been found to stimulate ERK- and PI3K-dependent elevation in the phosphorylation of CREB and to upregulate the levels of the ionotropic glutamate receptor 2 (GluR2) in cortical neurons and can therefore play a vital role as a modulator in synaptogenesis, plasticity, and neurotransmission [192]. It has been reported that adding blueberry to the diet of aged animals for twelve weeks can cause an increase in expression of the activity-regulated cytoskeletal-associated protein (Arc/Arg3.1), induction of hippocampal Akt phosphorylation, and activation of the downstream mammalian target of rapamycin (mTOR) [184]. As it has been suggested that Arc, under the regulatory control of both BDNF, is essential in long-term potentiation (LTP) [193], such alterations might underlie events associated to the spatial memory via the induction of morphological modifications and the facilitation of alterations in synaptic strength [194]. Interestingly, modifications in neuronal spine density and morphology are regarded as necessary for memory and learning [195]. Some studies have indicated that changes in neuronal morphology can take place due to supplementation with flavonoids $[180,196]$ and that the neuronal dendrite outgrowth in vitro can be affected by certain flavonoids [197]. 
NFTs accumulation and the hyperphosphorylation of tau are found to be strongly associated with cognitive impairments. In the case of $\mathrm{AD}$ pathogenesis, among the kinases that can phosphorylate tau, GSK-3 $\beta$ is intensely considered $[148,198]$. Indeed, it has been demonstrated that flavonoids exhibit beneficial effects through their inhibition of the action of certain kinases that play a role in $\mathrm{AD}$ pathology, as previously stated. Therefore, in the case of $\mathrm{AD}$, it appears to be sensible to conclude that disproportions in the phosphorylation system are thus one of the reasons for cytoskeletal protein hyperphosphorylation. Although there is no proof of the fact that flavonoids might influence signaling pathways through regulation of the activity of phosphatases, strong evidence is given for the capability of flavonoids to regulate kinases. It is possible that alterations in the activation of ERK and associated transcription factors might result from the flavonoid-mediated regulation of the activity of phosphatases, as phosphatases are integral to many signaling pathways and reverse the effects of kinases [151]. However, further studies are required to appraise the flavonoid's potential to activate or inhibit phosphatases and their mechanisms of action.

\section{Role of Flavonoids in Autophagy}

The human body uses autophagy in order to clean out damaged cells to regenerate healthier and newer cells $[199,200]$. Furthermore, autophagy also controls the production and the clearance of $A \beta$ [201]. To reduce synaptic defect and neuronal death, clearance of $A \beta$ from the brain is another main target for anti-AD drugs [202]. In the study of Pierzynowska et al. [203], it was shown that at a high dose (i.e., $150 \mathrm{mg} / \mathrm{kg} / \mathrm{day}$ ), genistein caused activation of autophagy in a streptozotocin-induced rat model of the sporadic AD. Moreover, at this high dose, the authors also noticed that genistein triggered the complete degradation of $A \beta$ and hyperphosphorylated tau via induction of autophagy [203].

The flavonoid, wogonin has also been reported to display the ability to promote the clearance of $\mathrm{A} \beta$ (Figure 4) in the primary cortical astrocytes and attenuate secretion of A $\beta$ in the SH-SY5Y cells that overexpress BACE1 and APP, via the mTOR/autophagy signaling pathway [204]. On the other hand, wogonin has the ability to suppress the P-glycoprotein, which is an ATP-binding cassette export protein with the function of transporting the drugs back into the blood. Nevertheless, the ability of this compound to penetrate the BBB is not confirmed by any direct evidence [205]. Interestingly, hesperetin and its glycoside hesperidin are other flavonoid compounds that can provide protection, through downregulation of the $A \beta$-activated autophagy, to neuronal cells against $A \beta$-stimulated impairment of glucose transport and glucose uptake [206]. Importantly, it has been reported in an in vitro ECV304/C6 monolayer co-culture BBB model, that hesperetin has the ability to penetrate the BBB [207]. Interestingly, quercetin can reduce $A \beta$ aggregation and the related paralysis via proteasomal degradation pathways and the activation of macroautophagy [98].

Chronic unpredictable mild stress is a causal factor in cases of neurodegenerative diseases, especially in $\mathrm{AD}$, since it can lead to the accumulation of $\mathrm{A} \beta$ and can also impede hippocampus-related memory and learning processes [208]. Interestingly, chronic unpredictable mild stress can be alleviated by ECG [208]. It has been observed that the activity of ECG is facilitated by the restoration of the autophagy flux in these brain areas, which further avoids those symptoms and impedes the progression of chronic unpredictable mild stress [208].

Silibinin is a flavonoid isolated from Silybum marianum. Silibinin improves the depressive behaviors induced by $\mathrm{A} \beta 42$ in rats and also alleviates neuronal damage by suppressing autophagy in the hippocampus [209]. Furthermore, this compound has also been found to protect neurons via suppressing both autophagic cell death and the mitochondrial pathways [210]. It has been reported by Jeong et al. [211] that naringin weakens autophagic stress in the kainic acid-treated hippocampus in vivo, which was verified by the expression of the microtubule-associated protein light chain 3 .

\section{Role of Flavonoids in Neuropathological Insults}

Due to metabolic events, several inappropriate events such as neuroinflammation, depletion of endogenous antioxidants, glutamatergic excitotoxicity and neurotoxicity occur as neurodegenerative 
outcomes in AD [212]. Various studies have revealed that the use of flavonoids helps to attenuate neuronal injuries and lessen the progression of neurodegeneration through regulating the components of kinase-signaling cascades, for example, the PI3K/Akt, PKC, and MAPK pathways [213,214]. ECG attenuates substantia nigra pars compacta damages through free radical chelation as well as regulating various signaling pathways such as PKC and PI3K which are responsible for neuroprotection $[215,216]$.

\section{Role of Flavonoids as Free Radicals' Scavengers}

During metabolic processes, various types of free radicals are produced. When free radicals are produced in excess, normal physiological processes are disturbed which leads to lipid peroxidation, protein degradation, DNA damage and deregulation of different chemokines [217]. Besides, these free radicals are also involved in the neuroinflammatory damage which proceeds to AD development [218,219]. A high level of oxidative stress biomarkers gives an indication of AD progression [220]. Furthermore, various studies established that patients of AD display low antioxidant power in their plasma [221,222]. Moreover, in the transgenic animal model of AD, high lipid peroxidation and protein degradation were reported [223]. Microglia activation is not only responsible for the production of pro-inflammatory cytokines, it also enhances the superoxide anion levels via the NADPH oxidase (NOX) which gives clues toward neurodegenerative events and AD [224-226].

Green tea contains strong antioxidants such as catechins and related polyphenols; these phytochemicals function as chelators of metal ions and scavengers of free radicals. ECG is responsible for the donation of electrons to the ROS-induced free radicals, thus inhibiting DNA damages linked to oxidative stress [227]. During lipid peroxidation by the iron ascorbate (i.e., labile ferri ferro complex), green tea lessens the progression of chain reactions in the mitochondrial membrane of brain cells. Due to the capacity of epigallocatechin gallate (EGCG) to inhibit fibril formation during A $\beta$ aggregation, it is considered as an effective scavenger among the catechins [228]. EGCG helps to attenuate lipid peroxidation that occurred due to $A \beta[229,230]$. It also lessens $A \beta$-induced programmed cell death and caspase activity, which enhances the survival of hippocampus neurons [229].

Quercetin is a strong antioxidant which has the ability to decrease the levels of superoxide anion free radicals. Thus, quercetin is useful in the management of multiple diseases, including AD [231]. In the study of Zhu et al. [232], 14 flavonoids were isolated and identified from Agrimonia pilosa Ledeb. Among these flavonoids, seven display significant 2,2-diphenyl-1-picrylhydrazyl (DPPH) free radical scavenging activities, namely luteolin-7-O- $\beta$-glucoside, rutin, hyperoside (3-O-quercetin galactoside), quercitrin, quercetin, luteolin and catechin with $\mathrm{IC}_{50}$ values of $8.12,6.36,6.34,7.12,4.36,7.29$ and $5.06 \mu \mathrm{M}$, respectively [232]. It has been revealed using the DNA nicking assay, that five flavonoids (i.e., rutin, quercitrin, hyperoside, catechin, and taxifolin) exhibited a significant protective effect against oxidative deoxyribonucleic acid damages [232]. A DPPH free radical scavenging activity has also been observed with the methanolic extracts from the stem bark of Artocarpus gomezianus [233]. Four flavonoids were isolated using the bio-assay guided fractionation of those methanolic extracts. These four flavonoids, including (+)-catechin, artobiloxanthone, cycloartobiloxanthone, and artonin E, exhibited significant DPPH free radical scavenging activity as well as showing a significant inhibitory activity on the production of nitric oxide in murine macrophage-like cells [233].

\section{Role of Flavonoids as Cholinesterase Inhibitors}

Acetylcholine $(\mathrm{ACh})$ is the neurotransmitter responsible for the signaling among synapses, which is degraded via enzymes such as acetylcholinesterase (AChE) and butyrylcholinesterase (BChE) [234]. As there are copious studies reporting low levels of ACh in AD brains [47,235,236], cholinesterase inhibitors thus represent the best therapeutic remedy to increase ACh levels at synaptic junctions [237]. Various studies have reported the use of flavonoids such as kaempferol, genistein, apigenin, quercetin, naringin, diosmin, silibinin, silymarin, as possible inhibitors of AChE and BChE. Among all these compounds, quercetin was found to exert the highest activity (i.e., 76.2\% of AChE inhibition), which is significantly higher compared to silibinin, genistein and luteolin (i.e., $51.4 \%$ and 65.7 , and 54.9\% 
of BChE inhibition, respectively) [238]. The study of Uriarte-Pueyo and Calvo [239] systematically summarized 128 flavonoids displaying an AChE-inhibiting activity, making flavonoids symptomatic anti-Alzheimer agents.

A research group has isolated and screened several potent flavonoids with cholinesterase inhibitors activity from the aerial part of Achillea millefolium (yarrow) [240]. It was shown that 6-OH-luteolin 7-O- $\beta$-D-glucoside had significant in silico and in vitro $\mathrm{BChE}$ and $\mathrm{AChE}$ inhibitory effects with an $\mathrm{IC}_{50}$ of 1.97 and $1.65 \mu \mathrm{M}$, respectively, in comparison with a standard of neostigmine ( $\mathrm{IC}_{50} 4.36$ and $\left.1.08 \mu \mathrm{M}\right)$. Collectively, these findings suggest that $6-\mathrm{OH}-$ luteolin $7-\mathrm{O}-\beta-\mathrm{D}$-glucoside might be developed as a novel therapeutic agent for AD management [240]. Another group has isolated 13 flavonoid derivatives along with two ginkgolides from the leaves of Ginkgo biloba. These compounds were screened to assess their possible acetylcholinesterase inhibitors (AChEIs) activity in vitro. It was quite evident from their $\mathrm{IC}_{50}$ values (ranging from 57.8 to $133.1 \mu \mathrm{g} / \mathrm{mL}$ ) that all these 13 derivatives showed significant AChEI activity in a dose-dependent manner as compared to the standard chlorpyrifos (i.e., an organophosphate insecticide, $\mathrm{IC}_{50} 12.4 \mu \mathrm{g} / \mathrm{mL}$ ). However, it was observed that the two ginkgolides (i.e., the ginkgolide $\mathrm{B}$ and C) were inactive against AChE [241]. Another study also reported the screening of several flavanols, flavanones, flavonols, isoflavones, and flavones for their inhibitory effect against Electrophorus electricus AChE [242]. Among all the studied compounds, the flavone baicalein exhibited the highest efficacy as an AChEI. The $\mathrm{IC}_{50}$ of this flavone was $0.61 \mu \mathrm{M}$ in comparison with the standard tacrine $\left(\mathrm{IC}_{50}\right.$ $25.4 \mu \mathrm{M})$ [242].

\section{Role of Flavonoids as Cognition Enhancers}

Flavonoid-rich food items have enormous biological effects on memory [104,243,244]. The isoflavones derived from soy as well as soy-derived foods are effective in learning and perception via mimicking the estrogen activity in the brain [245]. Furthermore, isoflavones also control the concentrations of $\mathrm{ACh}$ as well as various neurotrophic factors such as the nerve growth factor and the BDNF in the frontal cortex, as well as the hippocampus of the brain involved in cognitive function [246,247].

Grape juice, cocoa, and blueberry are used as memory-enhancers due to the presence of flavonoids [248-250]. Various studies have suggested that the administration of pure quercetin and EGCG, along with daily usage of flavonoid-rich fruits such as blueberry, pomegranate, strawberry, and grapes, enhance cognition, also affecting memory acquisition, retention, and recovery as well as short and long term memory [251,252]. However, there are fewer studies on cognition and spatial working memory in animal models fed with fruits with high flavonol and anthocyanin contents $[253,254]$. Furthermore, it has been noted that EGCG enhances the progression of the spatial memory [180], while the flavonoids from blueberry display the same action via their action on the dentate gyrus, which are most sensitive to the effects of aging $[255,256]$. Blueberry flavonoids lead to an enhancement of precursor cell proliferation in the dentate gyrus of animal models, which ultimately improves dentate gyrus neurogenesis and cognition [257].

Ettcheto et al. [258] have assessed the possible beneficial activity of EGCG in a well-established preclinical mixed model of familial AD and type 2 diabetes mellitus, based on the use of transgenic APPswe/PS1dE9 mice fed with a high-fat diet. Interestingly, treatment with EGCG improved memory impairments and insulin sensitivity. Additionally, EGCG significantly elevated the synaptic markers and rates of cAMP response element-binding phosphorylation by a reduction in the activation of the unfolded protein response (UPR), through the decrease in the posterior downregulation of protein tyrosine phosphatase 1B (PTP1B) as well as in the levels of the activation factor 4. EGCG also markedly reduced $A \beta$ generation in the brain and decreased the plaque burden by elevating the $\alpha$-secretase levels [258]. Unfortunately, the inherent instability of EGCG limits its effectiveness and bioavailability. Cano et al. [109] stated that oral treatment with dual-drug-loaded PEGylated PLGA (EGCG/ascorbic acid) caused the accumulation of EGCG in all major organs, including the brain, in a mouse model study. Interestingly, in APPswe/PS1dE9 mice, the oral administration of EGCG/ascorbic acid nanoparticles 
caused a significant rise in synapses, as evaluated by the expression of synaptophysin, a decrease in neuroinflammation and $\mathrm{A} \beta$ plaque burden, as well as a reduction in the cortical levels of insoluble and soluble $A \beta 42$. Moreover, these morphological alterations took place alongside marked enhancement in spatial memory and learning [109].

\section{Conclusions}

In natural foods, flavonoids are broadly available, and therefore AD treatments with such natural compounds via dietary supplements or diet can be regarded as an attractive substitute. In a range of animal and cell culture models, flavonoids have confirmed their beneficial effects against the AD pathogenesis. However, before putting novel flavonoid-based dietary applications in practice to lower the risk of $\mathrm{AD}$, further studies are required which will address the specific processes through which flavonoids exhibit their potential neuroprotective effects. In order to develop novel approaches for neuroprotection, understanding the processes underlying flavonoid-protein interactions in AD may represent an auspicious objective.

Author Contributions: M.S.U. conceived the original idea and designed the outlines of the study. M.S.U., M.T.K. and K.N. wrote the draft of the manuscript. M.S.U. prepared the figures for the manuscript. P.J. and C.C. edited the whole manuscript and improved the draft. B.M., A.R., K.R.R.R., E.S.-S., G.M.A. and L.A. performed the literature review and aided in revising the manuscript. All authors have read and agreed to the published version of the manuscript.

Funding: This project was supported by the Pharmakon Neuroscience Research Network, Dhaka, Bangladesh.

Acknowledgments: The authors concede the support by the Pharmakon Neuroscience Research Network, Dhaka, Bangladesh.

Conflicts of Interest: The authors declare no conflict of interest.

\section{References}

1. Al Mamun, A.; Uddin, M.S. KDS2010: A Potent Highly Selective and Reversible MAO-B Inhibitor to Abate Alzheimer's Disease. Comb. Chem. High Throughput Screen. 2020, 23. [CrossRef]

2. Uddin, M.S.; Kabir, M.T.; Al Mamun, A.; Abdel-Daim, M.M.; Barreto, G.E.; Ashraf, G.M. APOE and Alzheimer's Disease: Evidence Mounts that Targeting APOE4 may Combat Alzheimer's Pathogenesis. Mol. Neurobiol. 2019, 56, 2450-2465. [CrossRef] [PubMed]

3. Kabir, M.T.; Abu Sufian, M.; Uddin, M.S.; Begum, M.M.; Akhter, S.; Islam, A.; Mathew, B.; Islam, M.S.; Amran, M.S.; Md Ashraf, G. NMDA Receptor Antagonists: Repositioning of Memantine as Multitargeting Agent for Alzheimer's Therapy. Curr. Pharm. Des. 2019, 25, 3506-3518. [CrossRef] [PubMed]

4. Rahman, M.A.; Rahman, M.R.; Zaman, T.; Uddin, M.S.; Islam, R.; Abdel-Daim, M.M.; Rhim, H. Emerging Potential of Naturally Occurring Autophagy Modulator against Neurodegeneration. Curr. Pharm. Des. 2020, 26. [CrossRef] [PubMed]

5. Duyckaerts, C.; Delatour, B.; Potier, M.-C. Classification and basic pathology of Alzheimer disease. Acta Neuropathol. 2009, 118, 5-36. [CrossRef]

6. Iqbal, K.; Grundke-Iqbal, I. Alzheimer Review Series: Alzheimer neurofibrillary degeneration: Significance, etiopathogenesis, therapeutics and prevention. J. Cell. Mol. Med. 2007, 12, 38-55. [CrossRef]

7. Ittner, L.M.; Götz, J. Amyloid- $\beta$ and tau-A toxic pas de deux in Alzheimer's disease. Nat. Rev. Neurosci. 2011, 12, 67-72. [CrossRef]

8. Querfurth, H.W.; LaFerla, F.M. Alzheimer's Disease. N. Engl. J. Med. 2010, 362, 329-344. [CrossRef]

9. Bassil, N.; Grossberg, G.T. Novel Regimens and Delivery Systems in the Pharmacological Treatment of Alzheimer's Disease. CNS Drugs 2009, 23, 293-307. [CrossRef]

10. Uddin, M.S.; Al Mamun, A.; Asaduzzaman, M.; Hosn, F.; Abu Sufian, M.; Takeda, S.; Herrera-Calderon, O.; Abdel-Daim, M.M.; Uddin, G.M.S.; Noor, M.A.A.; et al. Spectrum of Disease and Prescription Pattern for Outpatients with Neurological Disorders: An Empirical Pilot Study in Bangladesh. Ann. Neurosci. 2018, 25, 25-37. [CrossRef] 
11. Uddin, M.S.; Mamun, A.A.; Takeda, S.; Sarwar, M.S.; Begum, M.M. Analyzing the chance of developing dementia among geriatric people: A cross-sectional pilot study in Bangladesh. Psychogeriatrics 2019, 19, 87-94. [CrossRef] [PubMed]

12. Soreq, H.; Seidman, S. Acetylcholinesterase-New roles for an old actor. Nat. Rev. Neurosci. 2001, 2, $294-302$. [CrossRef] [PubMed]

13. Sahab Uddin, M.; Shah Amran, M. Handbook of Research on Critical Examinations of Neurodegenerative Disorders, 1st ed.; IGI Global: Hershey, PA, USA, 2018; ISBN 9781522552826.

14. Li, Y. Biogen Posts Its Worst Day in a Decade after Ending Trial for Blockbuster Alzheimer's Drug. Available online: https://www.cnbc.com/2019/03/21/biogen-shares-plunge-more-than-25percent-after-ending-trialfor-alzheimers-drug-aducanumab.html (accessed on 25 October 2019).

15. Alicia Bigica Aducanumab Heads to the FDA After Biogen Analysis Proves Positive in Early Alzheimer Disease. Available online: https://www.neurologylive.com/clinical-focus/aducanumab-heads-to-the-fdaafter-biogen-analysis-proves-positive-in-early-alzheimer-disease (accessed on 25 October 2019).

16. Mancuso, C.; Siciliano, R.; Barone, E.; Preziosi, P. Natural substances and Alzheimer's disease: From preclinical studies to evidence based medicine. Biochim. Biophys. Acta Mol. Basis Dis. 2012, 1822, 616-624. [CrossRef] [PubMed]

17. Rahman, A.; Haque, A.; Uddin, M.S.; Mian, M.M.; Sufian, M.A.; Rahman, M.M.; Ali, Y.; Rafe, M.R.; Abdel-Daim, M.M.; Uddin, M.J.; et al. In vitro screening for antioxidant and anticholinesterase effects of Uvaria littoralis Blume.: A nootropic phytotherapeutic remedy. J. Intellect. Disabil. Diagnosis Treat. 2017, 5 , 50-60.

18. Nasrullah, M.; Haque, A.; Alzahrani, S.A.; Ashraf Uddin, M.; Yasmin, Z.; Sahab Uddin, M.; Almulaiky, Y.Q.; Kuerban, A. Acetylcholinesterase and butyrylcholinesterase enzyme inhibitory effect of Alangium salviifolium (L. f.) Wang pericarp extracts with their phytochemical and antioxidant values. J. Pharm. Res. Int. 2017, 19, 1-11. [CrossRef]

19. Uddin, M.S.; Al Mamun, A.; Kabir, M.T.; Jakaria, M.; Mathew, B.; Barreto, G.E.; Ashraf, G.M. Nootropic and Anti-Alzheimer's Actions of Medicinal Plants: Molecular Insight into Therapeutic Potential to Alleviate Alzheimer's Neuropathology. Mol. Neurobiol. 2019, 56, 4925-4944. [CrossRef]

20. Uddin, M.S.; Hossain, M.S.; Kabir, M.T.; Rahman, I.; Tewari, D.; Jamiruddin, M.R.; Al Mamun, A. Phytochemical screening and antioxidant profile of Syngonium podophyllum schott stems: A fecund phytopharmakon. J. Pharm. Nutr. Sci. 2018, 8, 120-128. [CrossRef]

21. Rasul, A.; Di, J.; Millimouno, F.; Malhi, M.; Tsuji, I.; Ali, M.; Li, J.; Li, X. Reactive Oxygen Species Mediate Isoalantolactone-Induced Apoptosis in Human Prostate Cancer Cells. Molecules 2013, 18, 9382-9396. [CrossRef]

22. Uddin, M.S.; Mamun, A.A.; Jakaria, M.; Thangapandiyan, S.; Ahmad, J.; Rahman, M.A.; Mathew, B.; Abdel-Daim, M.M.; Aleya, L. Emerging promise of sulforaphane-mediated Nrf2 signaling cascade against neurological disorders. Sci. Total Environ. 2020, 707, 1-12. [CrossRef]

23. Uddin, M.S.; Hossain, M.S.; Mamun, A.A.; Tewari, D.; Asaduzzaman, M.; Islam, M.S.; Abdel-Daim, M.M. Phytochemical analysis and antioxidant profile of methanolic extract of seed, pulp and peel of Baccaurea ramiflora Lour. Asian Pac. J. Trop. Med. 2018, 11, 443-450.

24. Uddin, M.S.; Uddin, G.M.S.; Begum, M.M.; Begum, Y.; Herrera-Calderon, O.; Islam, M.M.; Abdel-Daim, M.M. Inspection of phytochemical content and in vitro antioxidant profile of Gnaphalium luteoalbum L.: An unexplored phytomedicine. J. Pharm. Nutr. Sci. 2017, 7, 136-146. [CrossRef]

25. Liu, C.-M.; Ma, J.-Q.; Liu, S.-S.; Zheng, G.-H.; Feng, Z.-J.; Sun, J.-M. Proanthocyanidins improves lead-induced cognitive impairments by blocking endoplasmic reticulum stress and nuclear factor-kB-mediated inflammatory pathways in rats. Food Chem. Toxicol. 2014, 72, 295-302. [CrossRef] [PubMed]

26. Uddin, M.S.; Upaganlawar, A. Oxidative Stress and Antioxidant Defense Biomedical Value in Health and Diseases; Nova Science Publishers: Hauppauge, NY, USA, 2019; ISBN 9781536156874.

27. Uddin, M.S.; Kabir, M.T.; Tewari, D.; Mathew, B.; Aleya, L. Emerging signal regulating potential of small molecule biflavonoids to combat neuropathological insults of Alzheimer's disease. Sci. Total Environ. 2019, 700, 1-11. [CrossRef] [PubMed]

28. Zhang, Q.; Zhao, J.J.; Xu, J.; Feng, F.; Qu, W. Medicinal uses, phytochemistry and pharmacology of the genus Uncaria. J. Ethnopharmacol. 2015, 173, 48-80. [CrossRef] 
29. Elbaz, A.; Carcaillon, L.; Kab, S.; Moisan, F. Epidemiology of Parkinson's disease. Rev. Neurol. (Paris) 2016, 172, 14-26. [CrossRef]

30. Tysnes, O.-B.; Storstein, A. Epidemiology of Parkinson's disease. J. Neural Transm. 2017, 124, 901-905. [CrossRef]

31. Spencer, J.P.E.; Vafeiadou, K.; Williams, R.J.; Vauzour, D. Neuroinflammation: Modulation by flavonoids and mechanisms of action. Mol. Aspects Med. 2012, 33, 83-97. [CrossRef]

32. Nabavi, S.F.; Braidy, N.; Habtemariam, S.; Orhan, I.E.; Daglia, M.; Manayi, A.; Gortzi, O.; Nabavi, S.M. Neuroprotective effects of chrysin: From chemistry to medicine. Neurochem. Int. 2015, 90, 224-231. [CrossRef]

33. Kim, D.H.; Kim, S.; Jeon, S.J.; Son, K.H.; Lee, S.; Yoon, B.H.; Cheong, J.H.; Ko, K.H.; Ryu, J.H. Tanshinone I enhances learning and memory, and ameliorates memory impairment in mice via the extracellular signal-regulated kinase signalling pathway. Br. J. Pharmacol. 2009, 158, 1131-1142. [CrossRef]

34. Ashafaq, M.; Raza, S.S.; Khan, M.M.; Ahmad, A.; Javed, H.; Ahmad, M.E.; Tabassum, R.; Islam, F.; Siddiqui, M.S.; Safhi, M.M.; et al. Catechin Hydrate Ameliorates Redox Imbalance and Limits Inflammatory Response in Focal Cerebral Ischemia. Neurochem. Res. 2012, 37, 1747-1760. [CrossRef]

35. Li, Q.; Zhao, H.; Zhao, M.; Zhang, Z.; Li, Y. Chronic green tea catechins administration prevents oxidative stress-related brain aging in C57BL/6J mice. Brain Res. 2010, 1353, 28-35. [CrossRef] [PubMed]

36. Ejaz Ahmed, M.; Khan, M.M.; Javed, H.; Vaibhav, K.; Khan, A.; Tabassum, R.; Ashafaq, M.; Islam, F.; Safhi, M.M.; Islam, F. Amelioration of cognitive impairment and neurodegeneration by catechin hydrate in rat model of streptozotocin-induced experimental dementia of Alzheimer's type. Neurochem. Int. 2013, 62, 492-501. [CrossRef]

37. Prakash, D.; Sudhandiran, G. Dietary flavonoid fisetin regulates aluminium chloride-induced neuronal apoptosis in cortex and hippocampus of mice brain. J. Nutr. Biochem. 2015, 26, 1527-1539. [CrossRef] [PubMed]

38. Gomes, A.; Pimpão, R.C.; Fortalezas, S.; Figueira, I.; Miguel, C.; Aguiar, C.; Salgueiro, L.; Cavaleiro, C.; Gonçalves, M.J.; Clemente, A.; et al. Chemical characterization and bioactivity of phytochemicals from Iberian endemic Santolina semidentata and strategies for ex situ propagation. Ind. Crops Prod. 2015, 74, 505-513. [CrossRef]

39. Lin, L.; Ni, B.; Lin, H.; Zhang, M.; Li, X.; Yin, X.; Qu, C.; Ni, J. Traditional usages, botany, phytochemistry, pharmacology and toxicology of Polygonum multiflorum Thunb.: A review. J. Ethnopharmacol. 2015, 159, 158-183. [CrossRef] [PubMed]

40. Khan, H.; Marya; Amin, S.; Kamal, M.A.; Patel, S. Flavonoids as acetylcholinesterase inhibitors: Current therapeutic standing and future prospects. Biomed. Pharmacother. 2018, 101, 860-870. [CrossRef] [PubMed]

41. Al Mamun, A.; Uddin, M.S.; Kabir, M.T.; Khanum, S.; Sarwar, M.S.; Mathew, B.; Rauf, A.; Ahmed, M.; Ashraf, G.M. Exploring the Promise of Targeting Ubiquitin-Proteasome System to Combat Alzheimer's Disease. Neurotox. Res. 2020. [CrossRef]

42. Bishop, N.A.; Lu, T.; Yankner, B.A. Neural mechanisms of ageing and cognitive decline. Nature 2010, 464, 529-535. [CrossRef]

43. Uddin, M.S.; Kabir, M.T. Oxidative Stress in Alzheimer's Disease: Molecular Hallmarks of Underlying Vulnerability. In Biological, Diagnostic and Therapeutic Advances in Alzheimer's Disease; Springer: Singapore, 2019; pp. 91-115.

44. Schubert, D.; Maher, P. An alternative approach to drug discovery for Alzheimer's disease dementia. Future Med. Chem. 2012, 4, 1681-1688. [CrossRef]

45. Schubert, D.; Currais, A.; Goldberg, J.; Finley, K.; Petrascheck, M.; Maher, P. Geroneuroprotectors: Effective Geroprotectors for the Brain. Trends Pharmacol. Sci. 2018, 39, 1004-1007. [CrossRef]

46. Mathew, B.; Parambi, D.G.T.; Mathew, G.E.; Uddin, M.S.; Inasu, S.T.; Kim, H.; Marathakam, A.; Unnikrishnan, M.K.; Carradori, S. Emerging therapeutic potentials of dual-acting MAO and AChE inhibitors in Alzheimer's and Parkinson's diseases. Arch. Pharm. (Weinheim) 2019, 352, 1900177. [CrossRef] [PubMed]

47. Kabir, M.T.; Uddin, M.S.; Begum, M.M.; Thangapandiyan, S.; Rahman, M.S.; Aleya, L.; Mathew, B.; Ahmed, M.; Ashraf, G.M.; Barreto, G.E. Cholinesterase Inhibitors for Alzheimer's Disease: Multitargeting Strategy based on Anti-Alzheimer's Drugs Repositioning. Curr. Pharm. Des. 2019, 25, 3519-3535. [CrossRef] [PubMed]

48. Bateman, R.J.; Munsell, L.Y.; Morris, J.C.; Swarm, R.; Yarasheski, K.E.; Holtzman, D.M. Human amyloid- $\beta$ synthesis and clearance rates as measured in cerebrospinal fluid in vivo. Nat. Med. 2006, 12, 856-861. [CrossRef] [PubMed] 
49. Esparza, T.J.; Zhao, H.; Cirrito, J.R.; Cairns, N.J.; Bateman, R.J.; Holtzman, D.M.; Brody, D.L. Amyloid-beta oligomerization in Alzheimer dementia versus high-pathology controls. Ann. Neurol. 2013, 73, 104-119. [CrossRef]

50. Uddin, M.S.; Stachowiak, A.; Mamun, A.A.; Tzvetkov, N.T.; Takeda, S.; Atanasov, A.G.; Bergantin, L.B.; Abdel-Daim, M.M.; Stankiewicz, A.M. Autophagy and Alzheimer's Disease: From Molecular Mechanisms to Therapeutic Implications. Front. Aging Neurosci. 2018, 10, 1-18. [CrossRef]

51. Harkany, T.; Abrahám, I.; Timmerman, W.; Laskay, G.; Tóth, B.; Sasvári, M.; Kónya, C.; Sebens, J.B.; Korf, J.; Nyakas, C.; et al. beta-amyloid neurotoxicity is mediated by a glutamate-triggered excitotoxic cascade in rat nucleus basalis. Eur. J. Neurosci. 2000, 12, 2735-2745. [CrossRef]

52. Harilal, S.; Jose, J.; Parambi, D.G.T.; Kumar, R.; Mathew, G.E.; Uddin, M.S.; Kim, H.; Mathew, B. Advancements in nanotherapeutics for Alzheimer's disease: Current perspectives. J. Pharm. Pharmacol. 2019, 71, 1370-1383. [CrossRef]

53. Qiu, C.; Kivipelto, M.; von Strauss, E. Epidemiology of Alzheimer's disease: Occurrence, determinants, and strategies toward intervention. Dialogues Clin. Neurosci. 2009, 11, 111-128.

54. Serrano-Pozo, A.; Frosch, M.P.; Masliah, E.; Hyman, B.T. Neuropathological alterations in Alzheimer disease. Cold Spring Harb. Perspect. Med. 2011, 1, a006189. [CrossRef]

55. Mohorko, N.; Bresjanac, M. Tau protein and human tauopathies: An overview. Slov. Med. J. $2008,77$.

56. Kimura, T.; Whitcomb, D.J.; Jo, J.; Regan, P.; Piers, T.; Heo, S.; Brown, C.; Hashikawa, T.; Murayama, M.; Seok, H.; et al. Microtubule-associated protein tau is essential for long-term depression in the hippocampus. Philos. Trans. R. Soc. B Biol. Sci. 2013, 369, 20130144. [CrossRef] [PubMed]

57. Goedert, M.; Spillantini, M.G. A Century of Alzheimer's Disease. Science (80-.) 2006, 314, 777-781. [CrossRef] [PubMed]

58. Buée, L.; Bussière, T.; Buée-Scherrer, V.; Delacourte, A.; Hof, P.R. Tau protein isoforms, phosphorylation and role in neurodegenerative disorders. Brain Res. Brain Res. Rev. 2000, 33, 95-130. [CrossRef]

59. Kimura, T.; Yamashita, S.; Fukuda, T.; Park, J.-M.; Murayama, M.; Mizoroki, T.; Yoshiike, Y.; Sahara, N.; Takashima, A. Hyperphosphorylated tau in parahippocampal cortex impairs place learning in aged mice expressing wild-type human tau. EMBO J. 2007, 26, 5143-5152. [CrossRef] [PubMed]

60. Brion, J.-P. Neurofibrillary Tangles and Alzheimer's Disease. Eur. Neurol. 1998, 40, 130-140. [CrossRef] [PubMed]

61. Kidd, M. Paired helical filaments in electron microscopy of Alzheimer's disease. Nature 1963, 197, $192-193$. [CrossRef]

62. Kidd, M. Alzheimer's disease-An electron microscopical study. Brain 1964, 87, 307-320. [CrossRef]

63. Wiśniewski, H.M.; Narang, H.K.; Terry, R.D. Neurofibrillary tangles of paired helical filaments. J. Neurol. Sci. 1976, 27, 173-181. [CrossRef]

64. Crowther, R.A. Straight and paired helical filaments in Alzheimer disease have a common structural unit. Proc. Natl. Acad. Sci. USA 1991, 88, 2288-2292. [CrossRef]

65. Wegmann, S.; Jung, Y.J.; Chinnathambi, S.; Mandelkow, E.-M.; Mandelkow, E.; Muller, D.J. Human Tau Isoforms Assemble into Ribbon-like Fibrils That Display Polymorphic Structure and Stability. J. Biol. Chem. 2010, 285, 27302-27313. [CrossRef]

66. Sandbrink, R.; Masters, C.L.; Beyreuther, K. Beta A4-amyloid protein precursor mRNA isoforms without exon 15 are ubiquitously expressed in rat tissues including brain, but not in neurons. J. Biol. Chem. 1994, 269, 1510-1517. [PubMed]

67. Uddin, M.S.; Kabir, M.T.; Rahman, M.M.; Mathew, B.; Shah, M.A.; Ashraf, G.M. TV 3326 for Alzheimer's dementia: A novel multimodal ChE and MAO inhibitors to mitigate Alzheimer's-like neuropathology. J. Pharm. Pharmacol. 2020. [CrossRef] [PubMed]

68. Buxbaum, J.D.; Liu, K.-N.; Luo, Y.; Slack, J.L.; Stocking, K.L.; Peschon, J.J.; Johnson, R.S.; Castner, B.J.; Cerretti, D.P.; Black, R.A. Evidence That Tumor Necrosis Factor $\alpha$ Converting Enzyme Is Involved in Regulated $\alpha$-Secretase Cleavage of the Alzheimer Amyloid Protein Precursor. J. Biol. Chem. 1998, 273, 27765-27767. [CrossRef] [PubMed]

69. Allinson, T.M.J.; Parkin, E.T.; Turner, A.J.; Hooper, N.M. ADAMs family members as amyloid precursor protein alpha-secretases. J. Neurosci. Res. 2003, 74, 342-352. [CrossRef] 
70. Vassar, R.; Bennett, B.D.; Babu-Khan, S.; Kahn, S.; Mendiaz, E.A.; Denis, P.; Teplow, D.B.; Ross, S.; Amarante, P.; Loeloff, R.; et al. Beta-secretase cleavage of Alzheimer's amyloid precursor protein by the transmembrane aspartic protease BACE. Science 1999, 286, 735-741. [CrossRef]

71. Bennett, B.D.; Babu-Khan, S.; Loeloff, R.; Louis, J.-C.; Curran, E.; Citron, M.; Vassar, R. Expression Analysis of BACE2 in Brain and Peripheral Tissues. J. Biol. Chem. 2000, 275, 20647-20651. [CrossRef]

72. Cai, H.; Wang, Y.; McCarthy, D.; Wen, H.; Borchelt, D.R.; Price, D.L.; Wong, P.C. BACE1 is the major $\beta$-secretase for generation of $A \beta$ peptides by neurons. Nat. Neurosci. 2001, 4, 233-234. [CrossRef]

73. Cole, S.L.; Vassar, R. The Alzheimer's disease Beta-secretase enzyme, BACE1. Mol. Neurodegener. 2007, 2, 22. [CrossRef]

74. Zhang, H.; Ma, Q.; Zhang, Y.; Xu, H. Proteolytic processing of Alzheimer's $\beta$-amyloid precursor protein. J. Neurochem. 2012, 120, 9-21. [CrossRef]

75. Haass, C.; Schlossmacher, M.G.; Hung, A.Y.; Vigo-Pelfrey, C.; Mellon, A.; Ostaszewski, B.L.; Lieberburg, I.; Koo, E.H.; Schenk, D.; Teplow, D.B.; et al. Amyloid $\beta$-peptide is produced by cultured cells during normal metabolism. Nature 1992, 359, 322-325. [CrossRef]

76. Seubert, P.; Vigo-Pelfrey, C.; Esch, F.; Lee, M.; Dovey, H.; Davis, D.; Sinha, S.; Schiossmacher, M.; Whaley, J.; Swindlehurst, C.; et al. Isolation and quantification of soluble Alzheimer's $\beta$-peptide from biological fluids. Nature 1992, 359, 325-327. [CrossRef] [PubMed]

77. Henriques, A.G.; Vieira, S.I.; Crespo-López, M.E.; Guiomar de Oliveira, M.A.; da Cruz e Silva, E.F.; da Cruz e Silva, O.A.B. Intracellular sAPP retention in response to A $\beta$ is mapped to cytoskeleton-associated structures. J. Neurosci. Res. 2009, 87, 1449-1461. [CrossRef] [PubMed]

78. Henriques, A.G.; Vieira, S.I.; da Cruz e Silva, E.F.; da Cruz e Silva, O.A.B. A $\beta$ Hinders Nuclear Targeting of AICD and Fe65 in Primary Neuronal Cultures. J. Mol. Neurosci. 2009, 39, 248-255. [CrossRef] [PubMed]

79. Henriques, A.G.; Vieira, S.I.; da Cruz e Silva, E.F.; da Cruz e Silva, O.A.B. A $\beta$ promotes Alzheimer's disease-like cytoskeleton abnormalities with consequences to APP processing in neurons. J. Neurochem. 2010, 113, 761-771. [CrossRef]

80. Domingues, S.C.T.S.; Henriques, A.G.; Wu, W.; Da Cruz e Silva, E.F.; Da Cruz e Silva, O.A.B. Altered subcellular distribution of the Alzheimer's amyloid precursor protein under stress conditions. Ann. N. Y. Acad. Sci. 2007, 1096, 184-195. [CrossRef]

81. Henriques, A.G.; Domingues, S.C.T.S.; Fardilha, M.; da Cruz e Silva, E.F.; da Cruz e Silva, O.A.B. Sodium azide and 2-deoxy-D-glucose-induced cellular stress affects phosphorylation-dependent AbetaPP processing. J. Alzheimer's Dis. 2005, 7, 201-212; discussion 255-262. [CrossRef]

82. Oliveira, J.M.; Henriques, A.G.; Martins, F.; Rebelo, S.; da Cruz e Silva, O.A.B. Amyloid- $\beta$ Modulates Both $\mathrm{A} \beta \mathrm{PP}$ and Tau Phosphorylation. J. Alzheimer's Dis. 2015, 45, 495-507. [CrossRef]

83. Meraz-Ríos, M.A.; Toral-Rios, D.; Franco-Bocanegra, D.; Villeda-Hernández, J.; Campos-Peña, V. Inflammatory process in Alzheimer's Disease. Front. Integr. Neurosci. 2013, 7. [CrossRef]

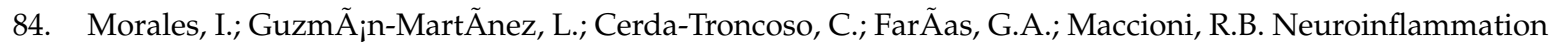
in the pathogenesis of Alzheimerâ $€^{\mathrm{TM}_{\mathrm{S}}}$ disease. A rational framework for the search of novel therapeutic approaches. Front. Cell. Neurosci. 2014, 8, 112. [CrossRef]

85. Walters, A.; Phillips, E.; Zheng, R.; Biju, M.; Kuruvilla, T. Evidence for neuroinflammation in Alzheimer's disease. Prog. Neurol. Psychiatry 2016, 20, 25-31. [CrossRef]

86. Shankar, G.M.; Walsh, D.M. Alzheimer's disease: Synaptic dysfunction and A $\beta$. Mol. Neurodegener. 2009, 4, 48. [CrossRef] [PubMed]

87. Mamun, A.; Uddin, M.; Mathew, B.; Ashraf, G. Toxic tau: Structural origins of tau aggregation in Alzheimer's disease. Neural Regen. Res. 2020, 15, 1417-1420. [CrossRef] [PubMed]

88. Martin, L.; Latypova, X.; Wilson, C.M.; Magnaudeix, A.; Perrin, M.-L.; Yardin, C.; Terro, F. Tau protein kinases: Involvement in Alzheimer's disease. Ageing Res. Rev. 2013, 12, 289-309. [CrossRef] [PubMed]

89. Gong, C.-X.; Iqbal, K. Hyperphosphorylation of microtubule-associated protein tau: A promising therapeutic target for Alzheimer disease. Curr. Med. Chem. 2008, 15, 2321-2328. [CrossRef] [PubMed]

90. Avila, J.; Lucas, J.J.; Pérez, M.; Hernández, F. Role of Tau Protein in Both Physiological and Pathological Conditions. Physiol. Rev. 2004, 84, 361-384. [CrossRef] [PubMed]

91. Köpke, E.; Tung, Y.C.; Shaikh, S.; Alonso, A.C.; Iqbal, K.; Grundke-Iqbal, I. Microtubule-associated protein tau. Abnormal phosphorylation of a non-paired helical filament pool in Alzheimer disease. J. Biol. Chem. 1993, 268, 24374-24384. 
92. Hollman, P.C.; Katan, M.B. Health effects and bioavailability of dietary flavonols. Free Radic. Res. 1999, 31 (Suppl. 1), 75-80. [CrossRef]

93. Uddin, M.S.; Kabir, M.T. Emerging signal regulating potential of genistein against Alzheimer's disease: A promising molecule of interest. Front. Cell Dev. Biol. 2019, 7, 1-12. [CrossRef]

94. Galli, R.L.; Shukitt-Hale, B.; Youdim, K.A.; Joseph, J.A. Fruit polyphenolics and brain aging: Nutritional interventions targeting age-related neuronal and behavioral deficits. Ann. N. Y. Acad. Sci. 2002, 959, 128-132. [CrossRef]

95. Unno, K.; Takabayashi, F.; Kishido, T.; Oku, N. Suppressive effect of green tea catechins on morphologic and functional regression of the brain in aged mice with accelerated senescence (SAMP10). Exp. Gerontol. 2004, 39, 1027-1034. [CrossRef]

96. Wang, Y.; Wang, L.; Wu, J.; Cai, J. The in vivo synaptic plasticity mechanism of EGb 761-induced enhancement of spatial learning and memory in aged rats. Br. J. Pharmacol. 2006, 148, 147-153. [CrossRef]

97. Sokolov, A.N.; Pavlova, M.A.; Klosterhalfen, S.; Enck, P. Chocolate and the brain: Neurobiological impact of cocoa flavanols on cognition and behavior. Neurosci. Biobehav. Rev. 2013, 37, 2445-2453. [CrossRef] [PubMed]

98. Zaplatic, E.; Bule, M.; Shah, S.Z.A.; Uddin, M.S.; Niaz, K. Molecular mechanisms underlying protective role of quercetin in attenuating Alzheimer's disease. Life Sci. 2019, 224, 109-119. [CrossRef] [PubMed]

99. Youdim, K.A.; Joseph, J.A. A possible emerging role of phytochemicals in improving age-related neurological dysfunctions: A multiplicity of effects. Free Radic. Biol. Med. 2001, 30, 583-594. [CrossRef]

100. Nabavi, S.M.; Šamec, D.; Tomczyk, M.; Milella, L.; Russo, D.; Habtemariam, S.; Suntar, I.; Rastrelli, L.; Daglia, M.; Xiao, J.; et al. Flavonoid biosynthetic pathways in plants: Versatile targets for metabolic engineering. Biotechnol. Adv. 2020, 38, 107316. [CrossRef] [PubMed]

101. Beecher, G.R. Overview of Dietary Flavonoids: Nomenclature, Occurrence and Intake. J. Nutr. 2003, 133, 3248S-3254S. [CrossRef] [PubMed]

102. Samsuzzaman, M.; Uddin, M.S.; Shah, M.A.; Mathew, B. Natural inhibitors on airway mucin: Molecular insight into the therapeutic potential targeting MUC5AC expression and production. Life Sci. 2019, 231, 116485. [CrossRef]

103. Pietta, P.G. Flavonoids as antioxidants. J. Nat. Prod. 2000, 63, 1035-1042. [CrossRef]

104. Spencer, J.P.E. Beyond antioxidants: The cellular and molecular interactions of flavonoids and how these underpin their actions on the brain. Proc. Nutr. Soc. 2010, 69, 244-260. [CrossRef]

105. Spencer, J.P.E. The impact of flavonoids on memory: Physiological and molecular considerations. Chem. Soc. Rev. 2009, 38, 1152. [CrossRef]

106. Paula, P.C.; Maria, S.G.A.; Luis, C.H.; Patricia, C.G.G. Preventive effect of quercetin in a triple transgenic Alzheimer's disease mice model. Molecules 2019, 24. [CrossRef]

107. Sachdeva, A.K.; Kuhad, A.; Chopra, K. Naringin ameliorates memory deficits in experimental paradigm of Alzheimer's disease by attenuating mitochondrial dysfunction. Pharmacol. Biochem. Behav. 2014, 127, 101-110. [CrossRef] [PubMed]

108. Yang, W.; Ma, J.; Liu, Z.; Lu, Y.; Hu, B.; Yu, H. Effect of naringenin on brain insulin signaling and cognitive functions in ICV-STZ induced dementia model of rats. Neurol. Sci. 2014, 35, 741-751. [CrossRef] [PubMed]

109. Cano, A.; Ettcheto, M.; Chang, J.H.; Barroso, E.; Espina, M.; Kühne, B.A.; Barenys, M.; Auladell, C.; Folch, J.; Souto, E.B.; et al. Dual-drug loaded nanoparticles of Epigallocatechin-3-gallate (EGCG)/Ascorbic acid enhance therapeutic efficacy of EGCG in a APPswe/PS1dE9 Alzheimer's disease mice model. J. Control. Release 2019, 301, 62-75. [CrossRef] [PubMed]

110. Jin Heo, H.; Lee, C.Y. Epicatechin and catechin in cocoa inhibit amyloid $\beta$ protein induced apoptosis. J. Agric. Food Chem. 2005, 53, 1445-1448.

111. Wang, H.; Wang, H.; Cheng, H.; Che, Z. Ameliorating effect of luteolin on memory impairment in an Alzheimer's disease model. Mol. Med. Rep. 2016, 13, 4215-4220. [CrossRef] [PubMed]

112. Sawmiller, D.; Habib, A.; Li, S.; Darlington, D.; Hou, H.; Tian, J.; Shytle, R.D.; Smith, A.; Giunta, B.; Mori, T.; et al. Diosmin reduces cerebral A $\beta$ levels, tau hyperphosphorylation, neuroinflammation, and cognitive impairment in the 3xTg-AD mice. J. Neuroimmunol. 2016, 299, 98-106. [CrossRef]

113. Huang, D.-S.; Yu, Y.-C.; Wu, C.-H.; Lin, J.-Y. Protective Effects of Wogonin against Alzheimer's Disease by Inhibition of Amyloidogenic Pathway. Evidence-Based Complement. Altern. Med. 2017, 2017, 3545169. [CrossRef] 
114. Uddin, M.S.; Mamun, A.A.; Hossain, M.S.; Ashaduzzaman, M.; Noor, M.A.A.; Hossain, M.S.; Uddin, M.J.; Sarker, J.; Asaduzzaman, M. Neuroprotective effect of Phyllanthus acidus L. on learning and memory impairment in scopolamine-induced animal model of dementia and oxidative stress: Natural wonder for regulating the development and progression of Alzheimer's disease. Adv. Alzheimer's Dis. 2016, 05, 53-72. [CrossRef]

115. Williams, R.J.; Spencer, J.P.E. Flavonoids, cognition, and dementia: Actions, mechanisms, and potential therapeutic utility for Alzheimer disease. Free Radic. Biol. Med. 2012, 52, 35-45. [CrossRef]

116. Flanagan, E.; Müller, M.; Hornberger, M.; Vauzour, D. Impact of Flavonoids on Cellular and Molecular Mechanisms Underlying Age-Related Cognitive Decline and Neurodegeneration. Curr. Nutr. Rep. 2018, 7 , 49-57. [CrossRef] [PubMed]

117. Guzzi, C.; Colombo, L.; Luigi, A.D.; Salmona, M.; Nicotra, F.; Airoldi, C. Flavonoids and Their Glycosides as Anti-amyloidogenic Compounds: A $\beta 1-42$ Interaction Studies to Gain New Insights into Their Potential for Alzheimer's Disease Prevention and Therapy. Chem. Asian J. 2017, 12, 67-75. [CrossRef] [PubMed]

118. Jiménez-Aliaga, K.; Bermejo-Bescós, P.; Benedí, J.; Martín-Aragón, S. Quercetin and rutin exhibit antiamyloidogenic and fibril-disaggregating effects in vitro and potent antioxidant activity in APPswe cells. Life Sci. 2011, 89, 939-945. [CrossRef] [PubMed]

119. Vepsäläinen, S.; Koivisto, H.; Pekkarinen, E.; Mäkinen, P.; Dobson, G.; McDougall, G.J.; Stewart, D.; Haapasalo, A.; Karjalainen, R.O.; Tanila, H.; et al. Anthocyanin-enriched bilberry and blackcurrant extracts modulate amyloid precursor protein processing and alleviate behavioral abnormalities in the APP/PS1 mouse model of Alzheimer's disease. J. Nutr. Biochem. 2013, 24, 360-370. [CrossRef] [PubMed]

120. Onozuka, H.; Nakajima, A.; Matsuzaki, K.; Shin, R.-W.; Ogino, K.; Saigusa, D.; Tetsu, N.; Yokosuka, A.; Sashida, Y.; Mimaki, Y.; et al. Nobiletin, a Citrus Flavonoid, Improves Memory Impairment and A Pathology in a Transgenic Mouse Model of Alzheimer's Disease. J. Pharmacol. Exp. Ther. 2008, 326, 739-744. [CrossRef]

121. Wang, J.; Ho, L.; Zhao, W.; Ono, K.; Rosensweig, C.; Chen, L.; Humala, N.; Teplow, D.B.; Pasinetti, G.M. Grape-Derived Polyphenolics Prevent A Oligomerization and Attenuate Cognitive Deterioration in a Mouse Model of Alzheimer's Disease. J. Neurosci. 2008, 28, 6388-6392. [CrossRef]

122. Rezai-Zadeh, K.; Douglas Shytle, R.; Bai, Y.; Tian, J.; Hou, H.; Mori, T.; Zeng, J.; Obregon, D.; Town, T.; Tan, J. Flavonoid-mediated presenilin-1 phosphorylation reduces Alzheimer's disease $\beta$-amyloid production. J. Cell. Mol. Med. 2009, 13, 574-588. [CrossRef]

123. Wang, Y.-J.; Thomas, P.; Zhong, J.-H.; Bi, F.-F.; Kosaraju, S.; Pollard, A.; Fenech, M.; Zhou, X.-F. Consumption of Grape Seed Extract Prevents Amyloid- $\beta$ Deposition and Attenuates Inflammation in Brain of an Alzheimer's Disease Mouse. Neurotox. Res. 2009, 15, 3-14. [CrossRef]

124. Augustin, S.; Rimbach, G.; Augustin, K.; Schliebs, R.; Wolffram, S.; Cermak, R. Effect of a short- and long-term treatment with Ginkgo biloba extract on Amyloid Precursor Protein Levels in a transgenic mouse model relevant to Alzheimer's disease. Arch. Biochem. Biophys. 2009, 481, 177-182. [CrossRef]

125. Mori, T.; Rezai-Zadeh, K.; Koyama, N.; Arendash, G.W.; Yamaguchi, H.; Kakuda, N.; Horikoshi-Sakuraba, Y.; Tan, J.; Town, T. Tannic Acid Is a Natural $\beta$-Secretase Inhibitor That Prevents Cognitive Impairment and Mitigates Alzheimer-like Pathology in Transgenic Mice. J. Biol. Chem. 2012, 287, 6912-6927. [CrossRef]

126. Shimmyo, Y.; Kihara, T.; Akaike, A.; Niidome, T.; Sugimoto, H. Flavonols and flavones as BACE-1 inhibitors: Structure-activity relationship in cell-free, cell-based and in silico studies reveal novel pharmacophore features. Biochim. Biophys. Acta Gen. Subj. 2008, 1780, 819-825. [CrossRef] [PubMed]

127. Shimmyo, Y.; Kihara, T.; Akaike, A.; Niidome, T.; Sugimoto, H. Epigallocatechin-3-gallate and curcumin suppress amyloid beta-induced beta-site APP cleaving enzyme-1 upregulation. Neuroreport 2008, 19, 1329-1333. [CrossRef] [PubMed]

128. Rezai-Zadeh, K.; Shytle, D.; Sun, N.; Mori, T.; Hou, H.; Jeanniton, D.; Ehrhart, J.; Townsend, K.; Zeng, J.; Morgan, D.; et al. Green Tea Epigallocatechin-3-Gallate (EGCG) Modulates Amyloid Precursor Protein Cleavage and Reduces Cerebral Amyloidosis in Alzheimer Transgenic Mice. J. Neurosci. 2005, 25, 8807-8814. [CrossRef] [PubMed]

129. Rezai-Zadeh, K.; Arendash, G.W.; Hou, H.; Fernandez, F.; Jensen, M.; Runfeldt, M.; Shytle, R.D.; Tan, J. Green tea epigallocatechin-3-gallate (EGCG) reduces $\beta$-amyloid mediated cognitive impairment and modulates tau pathology in Alzheimer transgenic mice. Brain Res. 2008, 1214, 177-187. [CrossRef] [PubMed] 
130. Obregon, D.F.; Rezai-Zadeh, K.; Bai, Y.; Sun, N.; Hou, H.; Ehrhart, J.; Zeng, J.; Mori, T.; Arendash, G.W.; Shytle, D.; et al. ADAM10 Activation Is Required for Green Tea (-)-Epigallocatechin-3-gallate-induced $\alpha$-Secretase Cleavage of Amyloid Precursor Protein. J. Biol. Chem. 2006, 281, 16419-16427. [CrossRef]

131. Simpkins, J.W.; Perez, E.; Wang, X.; Yang, S.; Wen, Y.; Singh, M. The potential for estrogens in preventing Alzheimer's disease and vascular dementia. Ther. Adv. Neurol. Disord. 2009, 2, 31-49. [CrossRef]

132. Fernandez, J.W.; Rezai-Zadeh, K.; Obregon, D.; Tan, J. EGCG functions through estrogen receptor-mediated activation of ADAM10 in the promotion of non-amyloidogenic processing of APP. FEBS Lett. 2010, 584, 4259-4267. [CrossRef]

133. Ehrnhoefer, D.E.; Bieschke, J.; Boeddrich, A.; Herbst, M.; Masino, L.; Lurz, R.; Engemann, S.; Pastore, A.; Wanker, E.E. EGCG redirects amyloidogenic polypeptides into unstructured, off-pathway oligomers. Nat. Struct. Mol. Biol. 2008, 15, 558-566. [CrossRef]

134. Bieschke, J.; Russ, J.; Friedrich, R.P.; Ehrnhoefer, D.E.; Wobst, H.; Neugebauer, K.; Wanker, E.E. EGCG remodels mature $\alpha$-synuclein and amyloid- $\beta$ fibrils and reduces cellular toxicity. Proc. Natl. Acad. Sci. USA 2010, 107, 7710-7715. [CrossRef]

135. Hirohata, M.; Hasegawa, K.; Tsutsumi-Yasuhara, S.; Ohhashi, Y.; Ookoshi, T.; Ono, K.; Yamada, M.; Naiki, H. The Anti-Amyloidogenic Effect Is Exerted against Alzheimer's $\beta$-Amyloid Fibrils in Vitro by Preferential and Reversible Binding of Flavonoids to the Amyloid Fibril Structure ${ }^{\dagger}$. Biochemistry 2007, 46, 1888-1899. [CrossRef]

136. Ono, K.; Yoshiike, Y.; Takashima, A.; Hasegawa, K.; Naiki, H.; Yamada, M. Potent anti-amyloidogenic and fibril-destabilizing effects of polyphenols in vitro: Implications for the prevention and therapeutics of Alzheimer's disease. J. Neurochem. 2003, 87, 172-181. [CrossRef] [PubMed]

137. Calani, L.; Dall'Asta, M.; Derlindati, E.; Scazzina, F.; Bruni, R.; Del Rio, D. Colonic metabolism of polyphenols from coffee, green tea, and hazelnut skins. J. Clin. Gastroenterol. 2012, 46, S95-S99. [CrossRef] [PubMed]

138. Monagas, M.; Urpi-Sarda, M.; Sánchez-Patán, F.; Llorach, R.; Garrido, I.; Gómez-Cordovés, C.; Andres-Lacueva, C.; Bartolomé, B. Insights into the metabolism and microbial biotransformation of dietary flavan-3-ols and the bioactivity of their metabolites. Food Funct. 2010, 1, 233-253. [CrossRef] [PubMed]

139. Wang, J.; Bi, W.; Cheng, A.; Freire, D.; Vempati, P.; Zhao, W.; Gong, B.; Janle, E.M.; Chen, T.Y.; Ferruzzi, M.G.; et al. Targeting multiple pathogenic mechanisms with polyphenols for the treatment of Alzheimer's disease-experimental approach and therapeutic implications. Front. Aging Neurosci. 2014, 6, 42. [CrossRef] [PubMed]

140. Fraga, C.G. (Ed.) Plant Phenolics and Human Health: Biochemistry, Nutrition, and Pharmacology; John Wiley and Sons: Hoboken, NJ, USA, 2009; ISBN 9780470287217.

141. Wang, D.; Ho, L.; Faith, J.; Ono, K.; Janle, E.M.; Lachcik, P.J.; Cooper, B.R.; Jannasch, A.H.; D'Arcy, B.R.; Williams, B.A.; et al. Role of intestinal microbiota in the generation of polyphenol-derived phenolic acid mediated attenuation of Alzheimer's disease $\beta$-amyloid oligomerization. Mol. Nutr. Food Res. 2015, 59, 1025-1040. [CrossRef] [PubMed]

142. Murakami, K.; Irie, K. Three structural features of functional food components and herbal medicine with amyloid $\beta 42$ anti-aggregation properties. Molecules 2019, 24, 2125. [CrossRef]

143. Taniguchi, S.; Suzuki, N.; Masuda, M.; Hisanaga, S.; Iwatsubo, T.; Goedert, M.; Hasegawa, M. Inhibition of Heparin-induced Tau Filament Formation by Phenothiazines, Polyphenols, and Porphyrins. J. Biol. Chem. 2005, 280, 7614-7623. [CrossRef]

144. Wang, J.; Santa-Maria, I.; Ho, L.; Ksiezak-Reding, H.; Ono, K.; Teplow, D.B.; Pasinetti, G.M. Grape Derived Polyphenols Attenuate Tau Neuropathology in a Mouse Model of Alzheimer's Disease. J. Alzheimer's Dis. 2010, 22, 653-661. [CrossRef]

145. Pasinetti, G.M.; Ksiezak-Reding, H.; Santa-Maria, I.; Wang, J.; Ho, L. Development of a grape seed polyphenolic extract with anti-oligomeric activity as a novel treatment in progressive supranuclear palsy and other tauopathies. J. Neurochem. 2010, 114, 1557-1568. [CrossRef]

146. Ho, L.; Yemul, S.; Wang, J.; Pasinetti, G.M. Grape Seed Polyphenolic Extract as a Potential Novel Therapeutic Agent in Tauopathies. J. Alzheimer's Dis. 2009, 16, 433-439. [CrossRef]

147. Ksiezak-Reding, H.; Ho, L.; Santa-Maria, I.; Diaz-Ruiz, C.; Wang, J.; Pasinetti, G.M. Ultrastructural alterations of Alzheimer's disease paired helical filaments by grape seed-derived polyphenols. Neurobiol. Aging 2012, 33, 1427-1439. [CrossRef] [PubMed] 
148. Leclerc, S.; Garnier, M.; Hoessel, R.; Marko, D.; Bibb, J.A.; Snyder, G.L.; Greengard, P.; Biernat, J.; Wu, Y.-Z.; Mandelkow, E.-M.; et al. Indirubins Inhibit Glycogen Synthase Kinase-3 $\beta$ and CDK5/P25, Two Protein Kinases Involved in Abnormal Tau Phosphorylation in Alzheimer's Disease. J. Biol. Chem. 2001, 276, 251-260. [CrossRef] [PubMed]

149. Gong, E.J.; Park, H.R.; Kim, M.E.; Piao, S.; Lee, E.; Jo, D.-G.; Chung, H.Y.; Ha, N.-C.; Mattson, M.P.; Lee, J. Morin attenuates tau hyperphosphorylation by inhibiting GSK3 $\beta$. Neurobiol. Dis. 2011, 44, 223-230. [CrossRef] [PubMed]

150. Qin, L.; Zhang, J.; Qin, M. Protective effect of cyanidin 3-O-glucoside on beta-amyloid peptide-induced cognitive impairment in rats. Neurosci. Lett. 2013, 534, 285-288. [CrossRef] [PubMed]

151. Spencer, J.P.E. The interactions of flavonoids within neuronal signalling pathways. Genes Nutr. 2007, 2, 257-273. [CrossRef] [PubMed]

152. Spencer, J.P.E.; Rice-Evans, C.; Williams, R.J. Modulation of Pro-survival Akt/Protein Kinase B and ERK1/2 Signaling Cascades by Quercetin and Its in Vivo Metabolites Underlie Their Action on Neuronal Viability. J. Biol. Chem. 2003, 278, 34783-34793. [CrossRef]

153. Incani, A.; Deiana, M.; Corona, G.; Vafeiadou, K.; Vauzour, D.; Dessì, M.A.; Spencer, J.P.E. Involvement of ERK, Akt and JNK signalling in $\mathrm{H} 2 \mathrm{O} 2$-induced cell injury and protection by hydroxytyrosol and its metabolite homovanillic alcohol. Mol. Nutr. Food Res. 2009, 54, 788-796. [CrossRef]

154. Vauzour, D.; Vafeiadou, K.; Spencer, J.P.E. Inhibition of the formation of the neurotoxin 5-S-cysteinyl-dopamine by polyphenols. Biochem. Biophys. Res. Commun. 2007, 362, 340-346. [CrossRef]

155. Jang, S.-W.; Liu, X.; Yepes, M.; Shepherd, K.R.; Miller, G.W.; Liu, Y.; Wilson, W.D.; Xiao, G.; Blanchi, B.; Sun, Y.E.; et al. A selective TrkB agonist with potent neurotrophic activities by 7,8-dihydroxyflavone. Proc. Natl. Acad. Sci. USA 2010, 107, 2687-2692. [CrossRef]

156. Lee, B.-H.; Choi, S.-H.; Shin, T.-J.; Pyo, M.K.; Hwang, S.-H.; Kim, B.-R.; Lee, S.-M.; Lee, J.-H.; Kim, H.-C.; Park, H.-Y.; et al. Quercetin enhances human $\alpha 7$ nicotinic acetylcholine receptor-mediated ion current through interactions with $\mathrm{Ca}^{2+}$ binding sites. Mol. Cells 2010, 30, 245-253. [CrossRef]

157. Lee, B.-H.; Choi, S.-H.; Shin, T.-J.; Pyo, M.K.; Hwang, S.-H.; Lee, S.-M.; Paik, H.-D.; Kim, H.-C.; Nah, S.-Y. Effects of quercetin on $\alpha 9 \alpha 10$ nicotinic acetylcholine receptor-mediated ion currents. Eur. J. Pharmacol. 2011, 650, 79-85. [CrossRef] [PubMed]

158. Katavic, P.L.; Lamb, K.; Navarro, H.; Prisinzano, T.E. Flavonoids as Opioid Receptor Ligands: Identification and Preliminary Structure-Activity Relationships. J. Nat. Prod. 2007, 70, 1278-1282. [CrossRef]

159. Panneerselvam, M.; Tsutsumi, Y.M.; Bonds, J.A.; Horikawa, Y.T.; Saldana, M.; Dalton, N.D.; Head, B.P.; Patel, P.M.; Roth, D.M.; Patel, H.H. Dark chocolate receptors: Epicatechin-induced cardiac protection is dependent on $\delta$-opioid receptor stimulation. Am. J. Physiol. Circ. Physiol. 2010, 299, H1604-H1609. [CrossRef] [PubMed]

160. Fernandez, S.P.; Mewett, K.N.; Hanrahan, J.R.; Chebib, M.; Johnston, G.A.R. Flavan-3-ol derivatives are positive modulators of GABAA receptors with higher efficacy for the $\alpha 2$ subtype and anxiolytic action in mice. Neuropharmacology 2008, 55, 900-907. [CrossRef] [PubMed]

161. Adachi, N.; Tomonaga, S.; Tachibana, T.; Denbow, D.M.; Furuse, M. (-)-Epigallocatechin gallate attenuates acute stress responses through GABAergic system in the brain. Eur. J. Pharmacol. 2006, 531, 171-175. [CrossRef]

162. Hanrahan, J.R.; Chebib, M.; Johnston, G.A.R. Flavonoid modulation of GABAA receptors. Br. J. Pharmacol. 2011, 163, 234-245. [CrossRef]

163. Ji, X.; Melman, N.; Jacobson, K.A. Interactions of Flavonoids and Other Phytochemicals with Adenosine Receptors. J. Med. Chem. 1996, 39, 781-788. [CrossRef]

164. Nifli, A.; Bossonkouame, A.; Papadopoulou, N.; Kogia, C.; Kampa, M.; Castagnino, C.; Stournaras, C.; Vercauteren, J.; Castanas, E. Monomeric and oligomeric flavanols are agonists of membrane androgen receptors. Exp. Cell Res. 2005, 309, 329-339. [CrossRef]

165. Han, Y.-S.; Bastianetto, S.; Dumont, Y.; Quirion, R. Specific Plasma Membrane Binding Sites for Polyphenols, Including Resveratrol, in the Rat Brain. J. Pharmacol. Exp. Ther. 2006, 318, 238-245. [CrossRef]

166. Agullo, G.; Gamet-Payrastre, L.; Manenti, S.; Viala, C.; Rémésy, C.; Chap, H.; Payrastre, B. Relationship between flavonoid structure and inhibition of phosphatidylinositol 3-kinase: A comparison with tyrosine kinase and protein kinase C inhibition. Biochem. Pharmacol. 1997, 53, 1649-1657. [CrossRef] 
167. Gamet-Payrastre, L.; Manenti, S.; Gratacap, M.P.; Tulliez, J.; Chap, H.; Payrastre, B. Flavonoids and the inhibition of PKC and PI 3-kinase. Gen. Pharmacol. 1999, 32, 279-286. [CrossRef]

168. Goyarzu, P.; Malin, D.H.; Lau, F.C.; Taglialatela, G.; Moon, W.D.; Jennings, R.; Moy, E.; Moy, D.; Lippold, S.; Shukitt-Hale, B.; et al. Blueberry Supplemented Diet: Effects on Object Recognition Memory and Nuclear Factor-kappa B Levels in Aged Rats. Nutr. Neurosci. 2004, 7, 75-83. [CrossRef] [PubMed]

169. Kong, A.N.; Yu, R.; Chen, C.; Mandlekar, S.; Primiano, T. Signal transduction events elicited by natural products: Role of MAPK and caspase pathways in homeostatic response and induction of apoptosis. Arch. Pharm. Res. 2000, 23, 1-16. [CrossRef] [PubMed]

170. Matter, W.F.; Brown, R.F.; Vlahos, C.J. The inhibition of phosphatidylinositol 3-kinase by quercetin and analogs. Biochem. Biophys. Res. Commun. 1992, 186, 624-631. [CrossRef]

171. Schroeter, H.; Spencer, J.P.E.; Rice-Evans, C.; Williams, R.J. Flavonoids protect neurons from oxidized low-density-lipoprotein-induced apoptosis involving c-Jun N-terminal kinase (JNK), c-Jun and caspase-3. Biochem. J. 2001, 358, 547. [CrossRef]

172. Williams, R.J.; Spencer, J.P.; Rice-Evans, C. Flavonoids: Antioxidants or signalling molecules? Free Radic. Biol. Med. 2004, 36, 838-849. [CrossRef]

173. Cobb, M.H.; Goldsmith, E.J. How MAP Kinases Are Regulated. J. Biol. Chem. 1995, 270, $14843-14846$. [CrossRef]

174. Cargnello, M.; Roux, P.P. Activation and Function of the MAPKs and Their Substrates, the MAPK-Activated Protein Kinases. Microbiol. Mol. Biol. Rev. 2011, 75, 50-83. [CrossRef]

175. Kobuchi, H.; Roy, S.; Sen, C.K.; Nguyen, H.G.; Packer, L. Quercetin inhibits inducible ICAM-1 expression in human endothelial cells through the JNK pathway. Am. J. Physiol. Physiol. 1999, 277, C403-C411. [CrossRef]

176. Llorens, F.; Garcia, L.; Itarte, E.; Gómez, N. Apigenin and LY294002 prolong EGF-stimulated ERK1/2 activation in PC12 cells but are unable to induce full differentiation. FEBS Lett. 2002, 510, 149-153. [CrossRef]

177. Schroeter, H.; Boyd, C.; Spencer, J.P.E.; Williams, R.J.; Cadenas, E.; Rice-Evans, C. MAPK signaling in neurodegeneration: Influences of flavonoids and of nitric oxide. Neurobiol. Aging 2002, 23, 861-880. [CrossRef]

178. Gopalakrishnan, A.; Xu, C.-J.; Nair, S.S.; Chen, C.; Hebbar, V.; Kong, A.-N.T. Modulation of activator protein-1 (AP-1) and MAPK pathway by flavonoids in human prostate cancer PC3 cells. Arch. Pharm. Res. 2006, 29, 633-644. [CrossRef] [PubMed]

179. Maher, P.; Akaishi, T.; Abe, K. Flavonoid fisetin promotes ERK-dependent long-term potentiation and enhances memory. Proc. Natl. Acad. Sci. USA 2006, 103, 16568-16573. [CrossRef]

180. van Praag, H.; Lucero, M.J.; Yeo, G.W.; Stecker, K.; Heivand, N.; Zhao, C.; Yip, E.; Afanador, M.; Schroeter, H.; Hammerstone, J.; et al. Plant-Derived Flavanol (-)Epicatechin Enhances Angiogenesis and Retention of Spatial Memory in Mice. J. Neurosci. 2007, 27, 5869-5878. [CrossRef] [PubMed]

181. Vauzour, D.; Vafeiadou, K.; Rice-Evans, C.; Williams, R.J.; Spencer, J.P.E. Activation of pro-survival Akt and ERK1/2 signalling pathways underlie the anti-apoptotic effects of flavanones in cortical neurons. J. Neurochem. 2007, 103, 1355-1367. [CrossRef] [PubMed]

182. Impey, S.; Smith, D.M.; Obrietan, K.; Donahue, R.; Wade, C.; Storm, D.R. Stimulation of cAMP response element (CRE)-mediated transcription during contextual learning. Nat. Neurosci. 1998, 1, 595-601. [CrossRef]

183. Finkbeiner, S.; Tavazoie, S.F.; Maloratsky, A.; Jacobs, K.M.; Harris, K.M.; Greenberg, M.E. CREB: A major mediator of neuronal neurotrophin responses. Neuron 1997, 19, 1031-1047. [CrossRef]

184. Williams, C.M.; El Mohsen, M.A.; Vauzour, D.; Rendeiro, C.; Butler, L.T.; Ellis, J.A.; Whiteman, M.; Spencer, J.P.E. Blueberry-induced changes in spatial working memory correlate with changes in hippocampal CREB phosphorylation and brain-derived neurotrophic factor (BDNF) levels. Free Radic. Biol. Med. 2008, 45, 295-305. [CrossRef]

185. Li, Q.; Zhao, H.F.; Zhang, Z.F.; Liu, Z.G.; Pei, X.R.; Wang, J.B.; Li, Y. Long-term green tea catechin administration prevents spatial learning and memory impairment in senescence-accelerated mouse prone- 8 mice by decreasing A $\beta 1-42$ oligomers and upregulating synaptic plasticity-related proteins in the hippocampus. Neuroscience 2009, 163, 741-749. [CrossRef]

186. Park, S.-S.; Bae, I.; Lee, Y.J. Flavonoids-induced accumulation of hypoxia-inducible factor (HIF)- $1 \alpha / 2 \alpha$ is mediated through chelation of iron. J. Cell. Biochem. 2008, 103, 1989-1998. [CrossRef] 
187. Feng, X.; Weng, D.; Zhou, F.; Owen, Y.D.; Qin, H.; Zhao, J.; WenYu; Huang, Y.; Chen, J.; Fu, H.; et al. Activation of PPAR $\gamma$ by a Natural Flavonoid Modulator, Apigenin Ameliorates Obesity-Related Inflammation Via Regulation of Macrophage Polarization. EBioMedicine 2016, 9, 61-76. [CrossRef] [PubMed]

188. Zhang, K.; Lu, J.; Mori, T.; Smith-Powell, L.; Synold, T.W.; Chen, S.; Wen, W. Baicalin increases VEGF expression and angiogenesis by activating the ERR $\alpha /$ PGC- $1 \alpha$ pathway. Cardiovasc. Res. 2011, 89, 426-435. [CrossRef] [PubMed]

189. Vlahos, C.J.; Matter, W.F.; Hui, K.Y.; Brown, R.F. A specific inhibitor of phosphatidylinositol 3-kinase, 2-(4-morpholinyl)-8-phenyl-4H-1-benzopyran-4-one (LY294002). J. Biol. Chem. 1994, 269, 5241-5248. [PubMed]

190. Ferriola, P.C.; Cody, V.; Middleton, E. Protein kinase C inhibition by plant flavonoids. Kinetic mechanisms and structure-activity relationships. Biochem. Pharmacol. 1989, 38, 1617-1624. [CrossRef]

191. Walker, E.H.; Pacold, M.E.; Perisic, O.; Stephens, L.; Hawkins, P.T.; Wymann, M.P.; Williams, R.L. Structural determinants of phosphoinositide 3-kinase inhibition by wortmannin, LY294002, quercetin, myricetin, and staurosporine. Mol. Cell 2000, 6, 909-919. [CrossRef]

192. Schroeter, H.; Bahia, P.; Spencer, J.P.E.; Sheppard, O.; Rattray, M.; Cadenas, E.; Rice-Evans, C.; Williams, R.J. (-)Epicatechin stimulates ERK-dependent cyclic AMP response element activity and up-regulates GluR2 in cortical neurons. J. Neurochem. 2007, 101, 1596-1606. [CrossRef]

193. Yin, Y.; Edelman, G.M.; Vanderklish, P.W. The brain-derived neurotrophic factor enhances synthesis of Arc in synaptoneurosomes. Proc. Natl. Acad. Sci. USA 2002, 99, 2368-2373. [CrossRef]

194. Waltereit, R.; Dammermann, B.; Wulff, P.; Scafidi, J.; Staubli, U.; Kauselmann, G.; Bundman, M.; Kuhl, D. Arg3.1/Arc mRNA induction by $\mathrm{Ca}^{2+}$ and cAMP requires protein kinase A and mitogen-activated protein kinase/extracellular regulated kinase activation. J. Neurosci. 2001, 21, 5484-5493. [CrossRef]

195. Harris, K.M.; Kater, S.B. Dendritic spines: Cellular specializations imparting both stability and flexibility to synaptic function. Annu. Rev. Neurosci. 1994, 17, 341-371. [CrossRef]

196. Haque, A.M.; Hashimoto, M.; Katakura, M.; Tanabe, Y.; Hara, Y.; Shido, O. Long-Term Administration of Green Tea Catechins Improves Spatial Cognition Learning Ability in Rats. J. Nutr. 2006, 136, 1043-1047. [CrossRef]

197. Reznichenko, L.; Amit, T.; Youdim, M.B.H.; Mandel, S. Green tea polyphenol (-)-epigallocatechin-3-gallate induces neurorescue of long-term serum-deprived PC12 cells and promotes neurite outgrowth. J. Neurochem. 2005, 93, 1157-1167. [CrossRef] [PubMed]

198. Llorens-Martín, M.; Jurado, J.; Hernández, F.; Ávila, J. GSK-3ß, a pivotal kinase in Alzheimer disease. Front. Mol. Neurosci. 2014, 7.

199. Uddin, M.S.; Mamun, A.A.; Labu, Z.K.; Hidalgo-Lanussa, O.; Barreto, G.E.; Ashraf, G.M. Autophagic dysfunction in Alzheimer's disease: Cellular and molecular mechanistic approaches to halt Alzheimer's pathogenesis. J. Cell. Physiol. 2019, 234, 8094-8112. [CrossRef] [PubMed]

200. Tanjir Islam, M.; Sahab Uddin, M.; Nahar Lucky, K.; Manjurul Islam, M.; Md Saiful Islam, S.; Tanvir Kabir, M.; Farhad Hossain, M.; Al Mamun, A.; Shah Amran, M. Autophagic Dysfunction in Type 2 Diabetes Mellitus: Pathophysiology and Therapeutic Implications. J. Diabetes Metab. 2017, 8, 1-8.

201. Nilsson, P.; Saido, T.C. Dual roles for autophagy: Degradation and secretion of Alzheimer's disease A $\beta$ peptide. BioEssays 2014, 36, 570-578. [CrossRef] [PubMed]

202. Lukiw, W.J. Amyloid beta (A $\beta$ ) peptide modulators and other current treatment strategies for Alzheimer's disease (AD). Expert Opin. Emerg. Drugs 2012. [CrossRef]

203. Pierzynowska, K.; Podlacha, M.; Gaffke, L.; Majkutewicz, I.; Mantej, J.; Węgrzyn, A.; Osiadły, M.; Myślińska, D.; Wegrzyn, G. Autophagy-dependent mechanism of genistein-mediated elimination of behavioral and biochemical defects in the rat model of sporadic Alzheimer's disease. Neuropharmacology 2019, 148, 332-346. [CrossRef]

204. Zhu, Y.; Wang, J. Wogonin increases $\beta$-amyloid clearance and inhibits tau phosphorylation via inhibition of mammalian target of rapamycin: Potential drug to treat Alzheimer's disease. Neurol. Sci. 2015, 36, 1181-1188. [CrossRef]

205. Yu, J.; Zhou, P.; Asenso, J.; Yang, X.-D.; Wang, C.; Wei, W. Advances in plant-based inhibitors of P-glycoprotein. J. Enzyme Inhib. Med. Chem. 2016, 31, 867-881. [CrossRef] 
206. Huang, S.-M.; Tsai, S.-Y.; Lin, J.-A.; Wu, C.-H.; Yen, G.-C. Cytoprotective effects of hesperetin and hesperidin against amyloid $\beta$-induced impairment of glucose transport through downregulation of neuronal autophagy. Mol. Nutr. Food Res. 2012, 56, 601-609. [CrossRef]

207. Youdim, K.A.; Dobbie, M.S.; Kuhnle, G.; Proteggente, A.R.; Abbott, N.J.; Rice-Evans, C. Interaction between flavonoids and the blood-brain barrier: In vitro studies. J. Neurochem. 2003, 85, 180-192. [CrossRef] [PubMed]

208. Gu, H.-F.; Nie, Y.-X.; Tong, Q.-Z.; Tang, Y.-L.; Zeng, Y.; Jing, K.-Q.; Zheng, X.-L.; Liao, D.-F. Epigallocatechin-3-Gallate Attenuates Impairment of Learning and Memory in Chronic Unpredictable Mild Stress-Treated Rats by Restoring Hippocampal Autophagic Flux. PLoS ONE 2014, 9, e112683. [CrossRef] [PubMed]

209. Song, X.; Liu, B.; Cui, L.; Zhou, B.; Liu, W.; Xu, F.; Hayashi, T.; Hattori, S.; Ushiki-Kaku, Y.; Tashiro, S.-I.; et al. Silibinin ameliorates anxiety/depression-like behaviors in amyloid $\beta$-treated rats by upregulating BDNF/TrkB pathway and attenuating autophagy in hippocampus. Physiol. Behav. 2017, 179, 487-493. [CrossRef] [PubMed]

210. Wang, M.; Li, Y.J.; Ding, Y.; Zhang, H.N.; Sun, T.; Zhang, K.; Yang, L.; Guo, Y.Y.; Liu, S.B.; Zhao, M.G.; et al. Silibinin Prevents Autophagic Cell Death upon Oxidative Stress in Cortical Neurons and Cerebral Ischemia-Reperfusion Injury. Mol. Neurobiol. 2016, 53, 932-943. [CrossRef] [PubMed]

211. Jeong, K.H.; Jung, U.J.; Kim, S.R. Naringin Attenuates Autophagic Stress and Neuroinflammation in Kainic Acid-Treated Hippocampus In Vivo. Evid.-Based Complement. Altern. Med. 2015, 2015, 354326. [CrossRef] [PubMed]

212. Jellinger, K.A. Cell death mechanisms in neurodegeneration. J. Cell. Mol. Med. 2001, 5, 1-17. [CrossRef]

213. Mandel, S.; Youdim, M.B. Catechin polyphenols: Neurodegeneration and neuroprotection in neurodegenerative diseases. Free Radic. Biol. Med. 2004, 37, 304-317. [CrossRef]

214. Spencer, J.P.E. Flavonoids: Modulators of brain function? Br. J. Nutr. 2008, 99, ES60-ES77. [CrossRef]

215. Mandel, S.A.; Avramovich-Tirosh, Y.; Reznichenko, L.; Zheng, H.; Weinreb, O.; Amit, T.; Youdim, M.B.H. Multifunctional Activities of Green Tea Catechins in Neuroprotection. Neurosignals 2005, 14, 46-60. [CrossRef]

216. Weinreb, O.; Amit, T.; Mandel, S.; Youdim, M.B.H. Neuroprotective molecular mechanisms of (-)-epigallocatechin-3-gallate: A reflective outcome of its antioxidant, iron chelating and neuritogenic properties. Genes Nutr. 2009, 4, 283-296. [CrossRef]

217. Markesbery, W.R.; Lovell, M.A. Damage to lipids, proteins, DNA, and RNA in mild cognitive impairment. Arch. Neurol. 2007, 64, 954-956. [CrossRef] [PubMed]

218. Solleiro-Villavicencio, H.; Rivas-Arancibia, S. Effect of chronic oxidative stress on neuroinflammatory response mediated by CD4+T cells in neurodegenerative diseases. Front. Cell. Neurosci. 2018, 12. [CrossRef] [PubMed]

219. Peña-Bautista, C.; Baquero, M.; Vento, M.; Cháfer-Pericás, C. Free radicals in Alzheimer's disease: Lipid peroxidation biomarkers. Clin. Chim. Acta 2019, 491, 85-90. [CrossRef] [PubMed]

220. Lovell, M.A.; Markesbery, W.R. Oxidative damage in mild cognitive impairment and early Alzheimer's disease. J. Neurosci. Res. 2007, 85, 3036-3040. [CrossRef]

221. Mecocci, P.; Polidori, M.C.; Cherubini, A.; Ingegni, T.; Mattioli, P.; Catani, M.; Rinaldi, P.; Cecchetti, R.; Stahl, W.; Senin, U.; et al. Lymphocyte Oxidative DNA Damage and Plasma Antioxidants in Alzheimer Disease. Arch. Neurol. 2002, 59, 794. [CrossRef]

222. Rinaldi, P.; Polidori, M.C.; Metastasio, A.; Mariani, E.; Mattioli, P.; Cherubini, A.; Catani, M.; Cecchetti, R.; Senin, U.; Mecocci, P. Plasma antioxidants are similarly depleted in mild cognitive impairment and in Alzheimer's disease. Neurobiol. Aging 2003, 24, 915-919. [CrossRef]

223. Resende, R.; Moreira, P.I.; Proença, T.; Deshpande, A.; Busciglio, J.; Pereira, C.; Oliveira, C.R. Brain oxidative stress in a triple-transgenic mouse model of Alzheimer disease. Free Radic. Biol. Med. 2008, 44, 2051-2057. [CrossRef]

224. Craft, J.M.; Watterson, D.M.; Van Eldik, L.J. Neuroinflammation: A potential therapeutic target. Expert Opin. Ther. Targets 2005, 9, 887-900. [CrossRef]

225. Balducci, C.; Forloni, G. Novel targets in Alzheimer's disease: A special focus on microglia. Pharmacol. Res. 2018, 130, 402-413. [CrossRef]

226. Park, L.; Zhou, P.; Pitstick, R.; Capone, C.; Anrather, J.; Norris, E.H.; Younkin, L.; Younkin, S.; Carlson, G.; McEwen, B.S.; et al. Nox2-derived radicals contribute to neurovascular and behavioral dysfunction in mice overexpressing the amyloid precursor protein. Proc. Natl. Acad. Sci. USA 2008, 105, 1347-1352. [CrossRef] 
227. Singh, M.; Arseneault, M.; Sanderson, T.; Murthy, V.; Ramassamy, C. Challenges for Research on Polyphenols from Foods in Alzheimer's Disease: Bioavailability, Metabolism, and Cellular and Molecular Mechanisms. J. Agric. Food Chem. 2008, 56, 4855-4873. [CrossRef] [PubMed]

228. Mandel, S.A.; Amit, T.; Weinreb, O.; Reznichenko, L.; Youdim, M.B.H. Simultaneous Manipulation of Multiple Brain Targets by Green Tea Catechins: A Potential Neuroprotective Strategy for Alzheimer and Parkinson Diseases. CNS Neurosci. Ther. 2008, 14, 352-365. [CrossRef] [PubMed]

229. Choi, Y.T.; Jung, C.H.; Lee, S.R.; Bae, J.H.; Baek, W.K.; Suh, M.H.; Park, J.; Park, C.W.; Suh, S.I. The green tea polyphenol (-)-epigallocatechin gallate attenuates beta-amyloid-induced neurotoxicity in cultured hippocampal neurons. Life Sci. 2001, 70, 603-614. [CrossRef]

230. Lee, J.W.; Lee, Y.K.; Ban, J.O.; Ha, T.Y.; Yun, Y.P.; Han, S.B.; Oh, K.W.; Hong, J.T. Green Tea (-)-Epigallocatechin-3-Gallate Inhibits $\beta$-Amyloid-Induced Cognitive Dysfunction through Modification of Secretase Activity via Inhibition of ERK and NF-kB Pathways in Mice. J. Nutr. 2009, 139, 1987-1993. [CrossRef]

231. Alok, S.; Jain, S.K.; Verma, A.; Kumar, M.; Mahor, A.; Sabharwal, M. Herbal antioxidant in clinical practice: A review. Asian Pac. J. Trop. Biomed. 2014, 4, 78-84. [CrossRef]

232. Zhu, L.; Chen, J.; Tan, J.; Liu, X.; Wang, B. Flavonoids from Agrimonia pilosa Ledeb: Free Radical Scavenging and DNA Oxidative Damage Protection Activities and Analysis of Bioactivity-Structure Relationship Based on Molecular and Electronic Structures. Molecules 2017, 22, 195. [CrossRef] [PubMed]

233. Sritularak, B.; Tantituvanont, A.; Chanvorachote, P.; Meksawan, K.; Miyamoto, T.; Kohno, Y.; Likhitwitayawuid, K. Flavonoids with free radical scavenging activity and nitric oxide inhibitory effect from the stem bark of Artocarpus gomezianus. J. Med. Plants Res. 2010, 4, 387-392.

234. Ayaz, M.; Sadiq, A.; Junaid, M.; Ullah, F.; Ovais, M.; Ullah, I.; Ahmed, J.; Shahid, M. Flavonoids as Prospective Neuroprotectants and Their Therapeutic Propensity in Aging Associated Neurological Disorders. Front. Aging Neurosci. 2019, 11, 155. [CrossRef] [PubMed]

235. Ferreira-Vieira, T.H.; Guimaraes, I.M.; Silva, F.R.; Ribeiro, F.M. Alzheimer's disease: Targeting the Cholinergic System. Curr. Neuropharmacol. 2016, 14, 101-115. [CrossRef]

236. Uddin, M.S.; Rashid, M. Advances in neuropharmacology: Drugs and therapeutics; Apple Academic Press: Burlington, ON, Canada, 2020; ISBN 9781771887977.

237. Bachman, D.L.; Wolf, P.A.; Linn, R.; Knoefel, J.E.; Cobb, J.; Belanger, A.; D'Agostino, R.B.; White, L.R. Prevalence of dementia and probable senile dementia of the Alzheimer type in the Framingham Study. Neurology 1992, 42, 115-119. [CrossRef]

238. Orhan, I.; Kartal, M.; Tosun, F.; Şener, B. Screening of Various Phenolic Acids and Flavonoid Derivatives for their Anticholinesterase Potential. Zeitschrift für Naturforsch. C 2007, 62, 829-832. [CrossRef] [PubMed]

239. Uriarte-Pueyo, I.; Calvo, M.I. Flavonoids as Acetylcholinesterase Inhibitors. Curr. Med. Chem. 2011, 18, 5289-5302. [CrossRef] [PubMed]

240. Sevindik, H.G.; Güvenalp, Z.; Yerdelen, K.Ö.; Yuca, H.; Demirezer, L.Ö. The discovery of potential anticholinesterase compounds from Achillea millefolium L. Ind. Crops Prod. 2015, 76, 873-879. [CrossRef]

241. Ding, X.; Ouyang, M.A.; Liu, X.; Wang, R.Z. Acetylcholinesterase inhibitory activities of flavonoids from the leaves of ginkgo biloba against brown planthopper. J. Chem. 2013. [CrossRef]

242. Balkis, A.; Tran, K.; Lee, Y.Z.; Ng, K. Screening Flavonoids for Inhibition of Acetylcholinesterase Identified Baicalein as the Most Potent Inhibitor. J. Agric. Sci. 2015, 7, p26. [CrossRef]

243. Commenges, D.; Scotet, V.; Renaud, S.; Jacqmin-Gadda, H.; Barberger-Gateau, P.; Dartigues, J.F. Intake of flavonoids and risk of dementia. Eur. J. Epidemiol. 2000, 16, 357-363. [CrossRef]

244. Letenneur, L.; Proust-Lima, C.; Le Gouge, A.; Dartigues, J.; Barberger-Gateau, P. Flavonoid Intake and Cognitive Decline over a 10-Year Period. Am. J. Epidemiol. 2007, 165, 1364-1371. [CrossRef]

245. File, S.; Jarrett, N.; Fluck, E.; Duffy, R.; Casey, K.; Wiseman, H. Eating soya improves human memory. Psychopharmacology (Berl.) 2001, 157, 430-436. [CrossRef]

246. Pan, Y.; Anthony, M.; Clarkson, T.B. Evidence for up-regulation of brain-derived neurotrophic factor mRNA by soy phytoestrogens in the frontal cortex of retired breeder female rats. Neurosci. Lett. 1999, 261, 17-20. [CrossRef]

247. Pan, Y.; Anthony, M.; Clarkson, T.B. Effect of Estradiol and Soy Phytoestrogens on Choline Acetyltransferase and Nerve Growth Factor mRNAs in the Frontal Cortex and Hippocampus of Female Rats. Proc. Soc. Exp. Biol. Med. 1999, 221, 118-125. [CrossRef] 
248. Krikorian, R.; Nash, T.A.; Shidler, M.D.; Shukitt-Hale, B.; Joseph, J.A. Concord grape juice supplementation improves memory function in older adults with mild cognitive impairment. Br. J. Nutr. 2010, 103, 730-734. [CrossRef] [PubMed]

249. Scholey, A.B.; French, S.J.; Morris, P.J.; Kennedy, D.O.; Milne, A.L.; Haskell, C.F. Consumption of cocoa flavanols results in acute improvements in mood and cognitive performance during sustained mental effort. J. Psychopharmacol. 2010, 24, 1505-1514. [CrossRef] [PubMed]

250. Shukitt-Hale, B. Blueberries and Neuronal Aging. Gerontology 2012, 58, 518-523. [CrossRef] [PubMed]

251. Hartman, R.E.; Shah, A.; Fagan, A.M.; Schwetye, K.E.; Parsadanian, M.; Schulman, R.N.; Finn, M.B.; Holtzman, D.M. Pomegranate juice decreases amyloid load and improves behavior in a mouse model of Alzheimer's disease. Neurobiol. Dis. 2006, 24, 506-515. [CrossRef] [PubMed]

252. Joseph, J.A.; Shukitt-Hale, B.; Denisova, N.A.; Bielinski, D.; Martin, A.; McEwen, J.J.; Bickford, P.C. Reversals of age-related declines in neuronal signal transduction, cognitive, and motor behavioral deficits with blueberry, spinach, or strawberry dietary supplementation. J. Neurosci. 1999, 19, 8114-8121. [CrossRef]

253. Joseph, J.A.; Shukitt-Hale, B.; Denisova, N.A.; Prior, R.L.; Cao, G.; Martin, A.; Taglialatela, G.; Bickford, P.C. Long-term dietary strawberry, spinach, or vitamin E supplementation retards the onset of age-related neuronal signal-transduction and cognitive behavioral deficits. J. Neurosci. 1998, 18, 8047-8055. [CrossRef]

254. Shukitt-Hale, B.; Cheng, V.; Joseph, J.A. Effects of blackberries on motor and cognitive function in aged rats. Nutr. Neurosci. 2009, 12, 135-140. [CrossRef]

255. Burke, S.N.; Barnes, C.A. Neural plasticity in the ageing brain. Nat. Rev. Neurosci. 2006, 7, 30-40. [CrossRef]

256. Small, S.A.; Chawla, M.K.; Buonocore, M.; Rapp, P.R.; Barnes, C.A. Imaging correlates of brain function in monkeys and rats isolates a hippocampal subregion differentially vulnerable to aging. Proc. Natl. Acad. Sci. USA 2004, 101, 7181-7186. [CrossRef]

257. Casadesus, G.; Shukitt-Hale, B.; Stellwagen, H.M.; Zhu, X.; Lee, H.-G.; Smith, M.A.; Joseph, J.A. Modulation of Hippocampal Plasticity and Cognitive Behavior by Short-term Blueberry Supplementation in Aged Rats. Nutr. Neurosci. 2004, 7, 309-316. [CrossRef]

258. Ettcheto, M.; Cano, A.; Manzine, P.R.; Busquets, O.; Verdaguer, E.; Castro-Torres, R.D.; García, M.L.; Beas-Zarate, C.; Olloquequi, J.; Auladell, C.; et al. Epigallocatechin-3-Gallate (EGCG) Improves Cognitive Deficits Aggravated by an Obesogenic Diet Through Modulation of Unfolded Protein Response in APPswe/PS1dE9 Mice. Mol. Neurobiol. 2019, 1-14. [CrossRef] [PubMed] 